\title{
Physiological responses of Daphnia pulex to acid stress
} Anna K Weber and Ralph Pirow*

\author{
Address: Institute of Zoophysiology, University of Münster, Münster, Germany \\ Email: Anna K Weber - akweber@gmx.de; Ralph Pirow* - pirow@uni-muenster.de \\ * Corresponding author
}

Published: 21 April 2009

BMC Physiology 2009, 9:9 doi:10.1186/1472-6793-9-9
Received: 29 February 2008

Accepted: 21 April 2009

This article is available from: http://www.biomedcentral.com/l472-6793/9/9

(C) 2009 Weber and Pirow; licensee BioMed Central Ltd.

This is an Open Access article distributed under the terms of the Creative Commons Attribution License (http://creativecommons.org/licenses/by/2.0), which permits unrestricted use, distribution, and reproduction in any medium, provided the original work is properly cited.

\begin{abstract}
Background: Acidity exerts a determining influence on the composition and diversity of freshwater faunas. While the physiological implications of freshwater acidification have been intensively studied in teleost fish and crayfish, much less is known about the acid-stress physiology of ecologically important groups such as cladoceran zooplankton. This study analyzed the extracellular acid-base state and $\mathrm{CO}_{2}$ partial pressure $\left(\mathrm{P}_{\mathrm{CO} 2}\right)$, circulation and ventilation, as well as the respiration rate of Daphnia pulex acclimated to acidic $(\mathrm{pH} 5.5$ and 6.0$)$ and circumneutral $(\mathrm{pH}$ 7.8) conditions.
\end{abstract}

Results: $D$. pulex had a remarkably high extracellular $\mathrm{pH}$ of 8.33 and extracellular $P_{\mathrm{CO}_{2}}$ of $0.56 \mathrm{kPa}$ under normal ambient conditions $(\mathrm{pH} 7.8$ and normocapnia). The hemolymph had a high bicarbonate concentration of $20.9 \mathrm{mM}$ and a total buffer value of $51.5 \mathrm{meq} \mathrm{L}^{-1} \mathrm{pH}^{-1}$. Bicarbonate covered $93 \%$ of the total buffer value. Acidic conditions induced a slight acidosis $(\Delta \mathrm{pH}=0.16-0.23)$, a $30-65 \%$ bicarbonate loss, and elevated systemic activities (tachycardia, hyperventilation, hypermetabolism). $\mathrm{pH} 6.0$ animals partly compensated the bicarbonate loss by increasing the nonbicarbonate buffer value from 2.0 to 5.1 meq $\mathrm{L}^{-1} \mathrm{pH}^{-1}$. The extracellular $\mathrm{P}_{\mathrm{CO} 2}$ of $\mathrm{pH} 5.5$ animals was significantly reduced to $0.33 \mathrm{kPa}$, and these animals showed the highest tolerance to a short-term exposure to severe acid stress.

Conclusion: Chronic exposure to acidic conditions had a pervasive impact on Daphnia's physiology including acid-base balance, extracellular $P_{\mathrm{CO} 2}$, circulation and ventilation, and energy metabolism. Compensatory changes in extracellular non-bicarbonate buffering capacity and the improved tolerance to severe acid stress indicated the activation of defense mechanisms which may result from gene-expression mediated adjustments in hemolymph buffer proteins and in epithelial properties. Mechanistic analyses of the interdependence between extracellular acid-base balance and $\mathrm{CO}_{2}$ transport raised the question of whether a carbonic anhydrase (CA) is involved in the catalysis of the $\mathrm{CO}_{2}-\mathrm{HCO}_{3}^{-}-\mathrm{H}^{+}$reaction, which led to the discovery of $31 \mathrm{CA}$-genes in the genome of $D$. pulex. 


\section{Background}

Freshwater acidification is an important stressor that affects the structure of zooplankton communities in lake ecosystems. Acidification may arise from natural processes such as spring acid episodes [1,2], acid rock drainage [3] and volcanism [4,5], or from anthropogenic activities including fossil fuels burning [6,7], agriculture measures $[8]$, dredging of waterways $[9,10]$ and mining-related processes (e.g. acid mine drainage, recultivation and flooding of former mining pits) $[11,12]$. $\mathrm{pH}$ levels below 5-6 generally decrease the zooplankton species richness compared to circumneutral pH conditions [13-16]. Among the zooplankton, crustaceans of the genus Daphnia are usually less abundant in acidified lakes while other (non-daphnid) cladocerans, calanoid copepods, and insects (e.g. Chaoborus larvae and corixids) may increase in importance or even become dominating $[15,17]$. The mechanisms behind these changes in the zooplankton community structure are manifold. They include a differential physiological sensitivity to acid stress $[14,18,19]$, a differential tolerance against toxic metal species [20-22], which become more soluble under acidic conditions, as well as altered biotic interactions arising from the effect of $\mathrm{pH}$ on phytoplankton and planktivore communities $[14,23]$.

It is well-known that the physiological sensitivity of aquatic animals to acidic conditions is associated with iono- and osmoregulatory processes $[24,25]$. Faced with the continuous diffusive gain of water and loss of ions, freshwater animals generally have to minimize their whole-body permeability to water and/or ions and additionally require compensatory uptake mechanisms for sodium and chloride to maintain a steady-state ion balance [26]. While data on whole-body water permeability of freshwater zooplankton are essentially lacking [27-29], there is some information on sodium permeability. In general, acid-tolerant species such as aquatic insects have a relatively low sodium permeability in comparison to cladocerans [18,30-32]. In the acid-sensitive daphnids, the inability to survive long term below pH 5 is correlated with the net loss of body sodium due to an accelerated rate of $\mathrm{Na}^{+}$loss and a reduced rate of $\mathrm{Na}^{+}$uptake [33,34], a process that is additionally influenced by the ambient calcium concentration [35].

The acidification-induced impairment of sodium uptake in daphnids suggests that the transport of sodium across the epipodites - the so-called 'branchial sacs' [36] - is linked with proton extrusion [33,35], as it is in the gills of other freshwater animals such as fish and crayfish [37-40]. The protons arise from the catalyzed hydration of $\mathrm{CO}_{2}$ by a cytoplasmic carbonic anhydrase in the ionoregulatory epithelia. This reaction produces $\mathrm{HCO}_{3}^{-}$which is then excreted in exchange for chloride [41]. The interdependence between ionoregulatory processes, acid-base balance, and $\mathrm{CO}_{2}$ transport explains the strong impact of acid stress on the physiology of many freshwater animals. However, in contrast to the detailed information on teleost fish [24] and crayfish [25], the physiological implications of acid stress in daphnids have remained largely unexplored. Daphnids are important model organisms in ecotoxicology, and there is a growing interest in establishing mechanistic links between molecular stress responses and organismal stress responses [42-47]. Understanding the specific physiology of Daphnia may help to elucidate the modes of action of environmental toxicants $[48,49]$.

The present study provides the experimental, methodical, and conceptual framework to analyze the acid-stress physiology of daphnids. Preliminary tests with Daphnia pulex yielded the appropriate acclimation conditions which guaranteed the survival, growth, and reproduction under acidic ( $\mathrm{pH} 5.5$ and 6.0) and circumneutral conditions ( $\mathrm{pH}$ 7.8 ). Based on these stable laboratory populations, we determined the buffer characteristics from microliter hemolymph samples, analyzed the extracellular acid-base state by microspectralfluorometry using the $\mathrm{pH}$-sensitive dye CSNARF-1, and studied the responses to a short-term exposure to severe acid stress ( $\mathrm{pH} 3-4$ ). Circulation, ventilation and respiration were additionally analyzed and served as diagnostic indicators for the interpretation of acid-base disturbances. Moreover, reproduction was monitored to assess acidification-induced changes in maintenance costs and energy-and-mass budget. Finally, the implications of the presence or absence of an extracellular carbonic anhydrase for acid-base balance and circulatory $\mathrm{CO}_{2}$ transport are discussed.

\section{Results and discussion Acid-base balance under normal conditions}

A rather alkaline extracellular $\mathrm{pH}$ of $8.334 \pm 0.006$ (mean \pm S.E., $N=4$ ) was measured in the heart region of animals which were raised and examined under normal conditions (i.e. ambient $\mathrm{pH}=7.8, P_{\mathrm{CO} 2}=0.035 \mathrm{kPa}$, and $20^{\circ} \mathrm{C}$ ). By taking the characteristics and the variability of the hemolymph buffer curves (Table 1) into account, the mean in vivo $\mathrm{pH}$ corresponded to an equilibrium $P_{\mathrm{CO} 2}$ of $0.56 \pm 0.02 \mathrm{kPa}$ (means \pm S.E., $N=3$ buffer curves) and a hemolymph bicarbonate concentration of $20.9 \pm 0.7 \mathrm{mM}$ (Table 2 and Figure 1A, open triangle). The derived $P_{\mathrm{CO} 2}$ value is a representative measure of the extracellular $P_{\mathrm{CO} 2}$ in the heart reagion as long as the $\mathrm{CO}_{2}+\mathrm{H}_{2} \mathrm{O} \leftrightarrow \mathrm{H}^{+}+\mathrm{HCO}_{3}^{-}$ reaction in the hemolymph can reasonably be assumed to be in equilibrium. The information on the hemolymph 

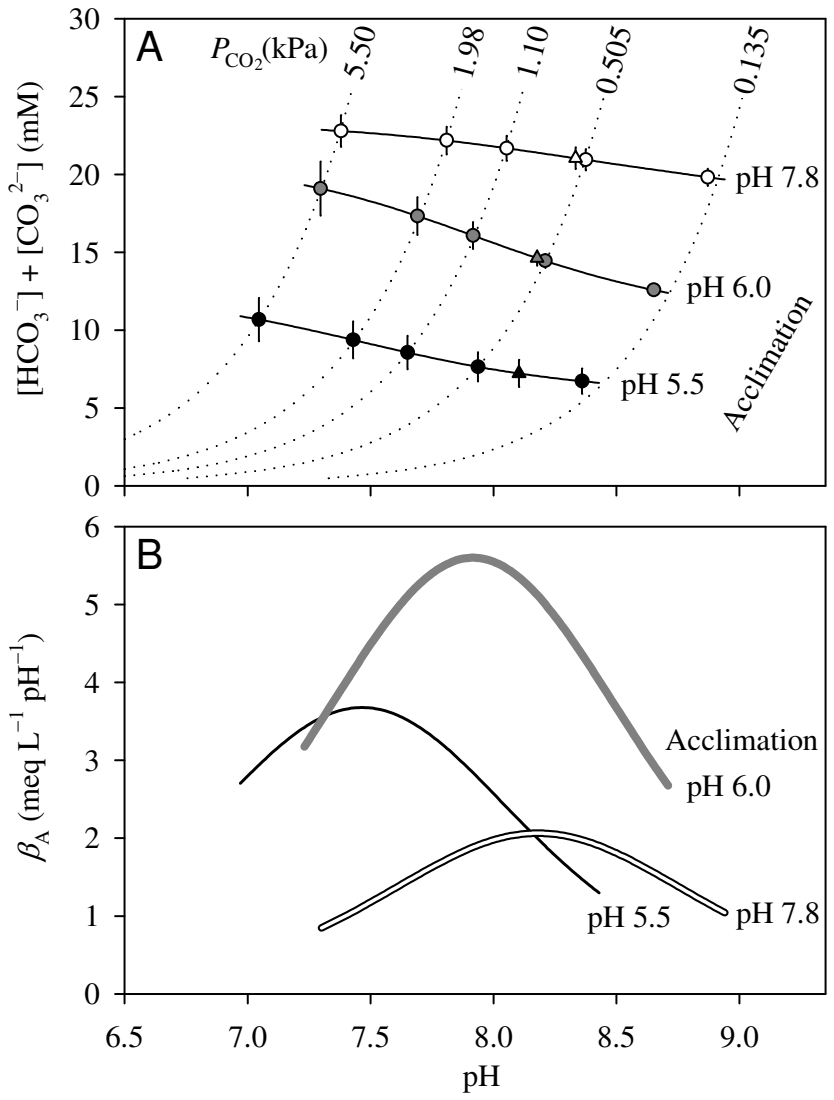

Figure I

Hemolymph buffer curves and non-bicarbonate buffer values. (A) Hemolymph buffer curves of animals raised at $20^{\circ} \mathrm{C}$ at $\mathrm{pH} 7.8$ (open symbols), $\mathrm{pH} 6.0$ (grey-filled symbols), and $\mathrm{pH} 5.5$ (filled symbols). The symbols represent the mean of a three-fold determination. The error in the concentration of chemically bound $\mathrm{CO}_{2}$ arises from the standard error in the calculation of $\mathrm{CO}_{2}$ partial pressure $\left(\mathrm{P}_{\mathrm{CO} 2}\right)$ for a given $\mathrm{pH}$ (Table I). The solid lines were calculated using the equations $\mathrm{I}-3$ and the means of the individual (curve-specific) parameter values given in Table I. Dotted lines represent the $P_{\mathrm{CO} 2}$ isobars. The triangles indicate the in vivo acid-base state of the respective acclimation groups. (B) Non-bicarbonate buffer values $\left(\beta_{\mathrm{A}}\right)$ calculated from equation 4.

buffer curves and the extracellular $\mathrm{pH}$ was used to assess the capacity of the extracellular compartment to buffer hydrogen ions of metabolic origin. The hemolymph had a total buffer value $\left(\beta_{\mathrm{T}}\right)$ of 51.5 meq $\mathrm{L}^{-1} \mathrm{pH}^{-1}$ (Table 2 ). Bicarbonate covered $93 \%$ of $\beta_{\Gamma^{\prime}}$ and the non-bicarbonate buffer value $\left(\beta_{\mathrm{A}}\right)$ was 2.0 meq $\mathrm{L}^{-1} \mathrm{pH}^{-1}$.

Given the extracellular $\mathrm{pH}$ of 8.334 , which is markedly higher than the circumneutral values of other waterbreathing crustaceans (Table 3) [50-70], one is tempted to assume that Daphnia pulex is in a state of permanent respi-
Table I: Analysis of hemolymph buffer curves and determination of $P_{\mathrm{CO}_{2}}$ from $\mathrm{pH}$.

\begin{tabular}{ccccc}
\hline Group & $\begin{array}{c}\text { SID } \\
\left(\mathbf{m e q} \mathbf{L}^{-1}\right)\end{array}$ & $\boldsymbol{C}_{\mathrm{A}}(\mathbf{m M})$ & $\mathrm{pK}_{\mathrm{A}}^{\prime}$ & rmse \\
\hline \multirow{2}{*}{$\mathrm{pH} \mathrm{7.8} \mathrm{acclimation}$} & $21.1 \pm 0.2$ & $2.3 \pm 0.3$ & $8.18 \pm 0.11$ & 0.003 \\
& $24.9 \pm 0.3$ & $5.2 \pm 0.3$ & & \\
& $23.9 \pm 0.2$ & $3.2 \pm 0.3$ & & \\
\hline \multirow{2}{*}{$\mathrm{pH} \mathrm{6.0} \mathrm{acclimation}$} & $20.9 \pm 0.8$ & $10.4 \pm 0.9$ & $7.92 \pm 0.11$ & 0.011 \\
& $25.0 \pm 1.2$ & $14.4 \pm 1.1$ & & \\
& $17.1 \pm 0.5$ & $4.4 \pm 0.7$ & & \\
\hline \multirow{2}{*}{$\mathrm{pH} \mathrm{5.5} \mathrm{acclimation}$} & $13.6 \pm 0.4$ & $7.4 \pm 0.4$ & $7.46 \pm 0.06$ & 0.006 \\
& $9.2 \pm 0.2$ & $4.4 \pm 0.2$ & & \\
& $14.6 \pm 0.4$ & $7.4 \pm 0.4$ & &
\end{tabular}

Buffer curves were obtained by measuring the $\mathrm{pH}$ of hemolymph samples in dependence on $\mathrm{CO}_{2}$ partial pressure $\left(P_{\mathrm{CO}_{2}}\right)$. The three buffer curves of each acclimation group were simultaneously fitted by the binary buffer model (equation I), using $\mathrm{PK}_{\mathrm{A}}$ as a shared parameter. This means that the value of this parameter was forced to be the same for all three buffer curves. Given are the best-fit parameter values (mean \pm standard error) for the strong ion difference (SID), the concentration $\left(C_{\mathrm{A}}\right)$ and $\mathrm{PK}_{\mathrm{A}}^{\prime}$ value of the nonbicarbonate buffer, and the the standard error of the fit (rmse, root mean squared error). The number for the degrees of freedom (i.e. the number of data points minus the number of fitted parameters) was 8 . The reverse determination of $P_{\mathrm{CO} 2}$ from $\mathrm{pH}$ is exemplified as follows. Given the in vivo $\mathrm{pH}$ of 8.334 , the three calibration buffer curves of the $\mathrm{pH} 7.8$ acclimation group yielded $\mathrm{P}_{\mathrm{CO} 2}$ values of $0.519 \pm$ $0.005 \mathrm{kPa}, 0.573 \pm 0.006 \mathrm{kPa}$, and $0.575 \pm 0.005 \mathrm{kPa}$. These individual means were finally averaged to yield an overall mean of $0.556 \mathrm{kPa}$ with a standard error of $0.018 \mathrm{kPa}$. This standard error therefore reflects the variability among the buffer curves.

ratory alkalosis. Indeed, the filter-feeding mode of life of daphnids is inevitably associated with high ventilation rates (e.g. $0.75 \mathrm{~mm}^{3} \mathrm{~s}^{-1}\left[\mathrm{~mm}^{-3}\right.$ body volume] for D. magna) [71], which should favor the wash-out of carbon dioxide from the hemolymph. However, the present study gave no indication for a respiratory hypocapnia in $D$. pulex, since the extracellular $\mathrm{pH}$ suggested an equilibrium $P_{\mathrm{CO} 2}$ of 0.56 $\mathrm{kPa}$, which is higher than the typical $P_{\mathrm{CO} 2}$ values $(0.2-0.5$ $\mathrm{kPa}$, Table 3) in the prebranchial and postbranchial hemolymph of other water-breathing crustaceans. If the equilibrium $P_{\mathrm{CO} 2}$ in the postbranchial hemolymph of $D$. pulex would approach the low value of, say, $0.2 \mathrm{kPa}$, an extreme alkalosis ( $\mathrm{pH} 8.75$ ) would occur. Taking the scaling relationship between metabolic rate and body size into account [72], the exceptional acid-base state of these small crustaceans seems to be determined by two main factors: (i) a high, specific metabolic rate, which contributes to the elevated $P_{\mathrm{CO} 2}$ levels, and (ii) a high bicarbonate buffer value, which might be a pre-adaptive feature to cope with a highly variable, physiologically challenging environment.

One may argue that the in vivo results are to some extent influenced by the experimental procedures, which 
Table 2: Comparison of acid-base, systemic and respiratory variables among the different acclimation groups.

\begin{tabular}{|c|c|c|c|c|}
\hline Physiological Variable & pH 7.8 acclimation & pH 6.0 acclimation & pH 5.5 acclimation & $\begin{array}{c}\text { Significant difference among acclimation } \\
\text { groups }\end{array}$ \\
\hline $\mathrm{pH}$ & $8.334 \pm 0.006 \dagger$ & $8.177 \pm 0.025$ & $8.104 \pm 0.008 \#$ & **** \\
\hline$P_{\mathrm{CO}_{2}}(\mathrm{kPa})$ & $0.56 \pm 0.02$ & $0.56 \pm 0.02$ & $0.33 \pm 0.04 \#$ & $* * * *$ \\
\hline $\mathrm{HCO}_{3}^{-}(\mathrm{mM})$ & $20.9 \pm 0.7$ & $14.6 \pm 0.5^{\#}$ & $7.2 \pm 0.9 \#$ & $* * *$ \\
\hline $\mathrm{CO}_{3}^{2-}(\mathrm{mM})$ & $0.153 \pm 0.005$ & $0.074 \pm 0.003$ & $0.031 \pm 0.007$ & $* * *$ \\
\hline$\beta_{\mathrm{A}}\left(\right.$ meq $\left.\mathrm{L}^{-1} \mathrm{pH}^{-1}\right)$ & 2.0 & 5.1 & 2.2 & not tested \\
\hline$\beta_{\mathrm{B}}\left(\right.$ meq L-1 $\left.\mathrm{pH}^{-1}\right)$ & 48.1 & 33.5 & 16.6 & not tested \\
\hline$\beta_{\mathrm{C}}\left(\right.$ meq $\left.\mathrm{L}^{-1} \mathrm{pH}^{-1}\right)$ & 0.70 & 0.34 & 0.14 & not tested \\
\hline$\beta_{\mathrm{T}}\left(\right.$ meq L-1 $\left.\mathrm{pH}^{-1}\right)$ & 51.5 & 39.4 & 19.1 & not tested \\
\hline$f_{H}\left(\min ^{-1}\right)$ & $205 \pm 10^{\dagger}$ & $246 \pm 18$ & $299 \pm 12^{\#}$ & ** \\
\hline$f_{A}\left(\min ^{-1}\right)$ & $374 \pm 32 \dagger$ & $427 \pm 58$ & $500 \pm 6 \#$ & $*$ \\
\hline$\dot{M}_{\mathrm{O}_{2}}\left(\mathrm{nmol} \mathrm{h}^{-1} \mathrm{~mm}^{-3}\right)$ & $1.53 \pm 0.09$ & $1.95 \pm 0.07 \dagger \#$ & $1.41 \pm 0.14 \dagger$ & $* *$ \\
\hline
\end{tabular}

$P_{\mathrm{CO} 2}, \mathrm{CO}_{2}$ partial pressure; $\beta_{\mathrm{A}}$, buffer value of the non-bicarbonate buffer; $\beta_{\mathrm{B}}$ and $\beta_{\mathrm{C}}$, bicarbonate and carbonate buffer value; $\beta_{\top}$, total buffer value (= $\left.\beta_{\mathrm{A}}+\beta_{\mathrm{B}}+2 \beta_{\mathrm{C}}\right) ; f_{\mathrm{H}}$, heart rate; $f_{\mathrm{A}}$, appendage beating rate; $\dot{M}_{\mathrm{O}_{2}}$, specific oxygen consumption rate (per cubic body length). Data are expressed as means \pm standard error, except for the buffer values which are given as means. The number of independent determinations $(N)$ is 3 , if not otherwise indicated. The $P_{\mathrm{CO} 2}$ was calculated from the mean $\mathrm{pH}$ value and the three corresponding buffer curves (Table I). Asterisks indicate significant differences among the acclimation groups $(* P<0.05$, $* * P<0.01$, $* * * P<0.001)$. \#significant difference between an acid-stress ( $\mathrm{pH} 6.0$ or $\mathrm{pH}$ 5.5) group and the control ( $\mathrm{pH} 7.8)$ group. $\mathrm{N}=4$.

required the microinjection of a $\mathrm{pH}$-sensitive dye into the circulatory system of immobilized animals. Previous studies $[71,73-75]$ have shown that the immobilization does not induce any noticable physiological disturbances, provided that the animals have the chance to acclimate to the experimental conditions for at least $30 \mathrm{~min}$. Immobilized animals of $D$. magna, for example, exhibit the typical resting values in heart rate $\left(f_{\mathrm{H}}\right)$ and appendage beating rate $\left(f_{\mathrm{A}}\right)$ and respond in a predictable manner to changes in abiotic [73-75] and biotic factors [71]. The microinjection procecure, however, is known to induce a bradycardia in D. magna [76] and it did so in D. pulex. Our microinjected control animals (pH 7.8 acclimation) had a $f_{\mathrm{H}}$ of $205 \pm 10$ $\min ^{-1}(N=4)$, which was significantly lower than that of non-injected animals $\left(310 \pm 28 \min ^{-1}, N=5\right.$; $t$-test: $P=$ $0.01)$. In contrast, there was no significant effect on $f_{\mathrm{A}}$ (injected: $374 \pm 32 \mathrm{~min}^{-1}$, non-injected: $352 \pm 51 \mathrm{~min}^{-1} ; P$ $=0.8$ ). The slower $f_{\mathrm{H}}$ was very likely caused by the increase in hemolymph viscosity due to the injection of the dye- coupled $70-\mathrm{kDa}$ dextrans. Given the $34 \%$ reduction in $f_{\mathrm{H}}$ one may suppose a pertubation in the hemolymph partial pressures of respiratory gases including the $P_{\mathrm{CO} 2}$. Theoretical analyses in terms of the $\mathrm{CO}_{2}$ transport model, which is described below, revealed that the mean extracellular $P_{\mathrm{CO} 2}$ would be $8 \%$ smaller in the absence of a bradycardia. An effect of this magnitude does not invalidate the findings about the exceptional acid-base state of $D$. pulex.

\section{Physiological and visible effects of chronic exposure to acidic conditions}

Animals raised and tested under acidic conditions (ambient $\mathrm{pH} 6.0$ and $\mathrm{pH} 5.5$ ) had extracellular $\mathrm{pH}$ values of $8.177 \pm 0.025$ and $8.104 \pm 0.008(N=3$ each $)$, respectively. These values were $0.16-0.23 \mathrm{pH}$ units lower than that of the control (pH 7.8 acclimated) animals. The differences in extracellular $\mathrm{pH}$ among the acclimation groups were statistically significant (Table 2). The extracellular $P_{\mathrm{CO} 2}(0.56 \pm 0.02 \mathrm{kPa})$ of the $\mathrm{pH} 6.0$ acclimated animals 
Table 3: Acid-base status in Crustacea.

\begin{tabular}{|c|c|c|c|c|c|c|c|c|}
\hline Group/Species & $\mathrm{pH}$ & {$\left[\mathrm{HCO}_{3}^{-}\right](\mathbf{m M})$} & $P_{\mathrm{CO} 2}(\mathrm{kPa})$ & $\begin{array}{l}\text { arterial/ } \\
\text { venous }\end{array}$ & $\beta_{\mathrm{A}}\left(\mathrm{mM} \mathbf{p H}^{-1}\right)$ & $T\left({ }^{\circ} \mathrm{C}\right)$ & Medium & $\begin{array}{l}\text { Mode of Reference } \\
\text { Life }\end{array}$ \\
\hline
\end{tabular}

\section{Branchiopoda}

\begin{tabular}{|c|c|c|c|c|c|c|c|c|c|}
\hline Daphnia pulex & 8.33 & 21.0 & 0.56 & & 1.75 & 20 & $\mathrm{FW}$ & A & $\S$ \\
\hline Daphnia magna & 8.44 & 13.4 & 0.28 & & 0.5 & 20 & $\mathrm{FW}$ & A & $\$$ \\
\hline Triops cancriformis & 7.52 & 7.6 & 1.36 & & 2.1 & 20 & $\mathrm{FW}$ & A & $\$$ \\
\hline \multicolumn{10}{|l|}{ Decapoda } \\
\hline Astacus astacus & 7.78 & 5.2 & 0.27 & $\mathrm{a}$ & 6.3 & 15 & $\mathrm{FW}$ & $A$ & [79] \\
\hline Astacus leptodactylus & 7.87 & 4.5 & 0.26 & $\mathrm{v}$ & 11.6 & 13 & $\mathrm{FW}$ & A & [6I] \\
\hline Pacifastacus leniusculus & 7.95 & $8.8^{\#}$ & 0.37 & $\mathrm{a}$ & 11.6 & 15 & $\mathrm{FW}$ & A & [69] \\
\hline Austropotamobius pallipes & 7.90 & $6.9 \#$ & 0.40 & $\mathrm{a}$ & 13.5 & 15 & $\mathrm{FW}$ & A & [64] \\
\hline Orconectes rusticus & 7.87 & $5.8^{\#}$ & 0.45 & $\mathrm{a}$ & & 15 & $\mathrm{FW}$ & A & [70] \\
\hline Orconectes propinquus & 7.75 & 7.0 & 0.37 & $\mathrm{a}$ & 8 & 10 & $\mathrm{FW}$ & A & [78] \\
\hline Procambarus clarki & 7.93 & 9.9 & 0.49 & $\mathrm{a}$ & & 15 & $\mathrm{FW}$ & A & [77] \\
\hline Procambarus clarki & 8.17 & 17.8 & 0.44 & $\mathrm{a}$ & & 15 & $\mathrm{FW}$ & A & [77] \\
\hline Procambarus clarki & 7.75 & 7.0 & 0.40 & $\mathrm{a}$ & & & $\mathrm{FW}$ & A & [25] \\
\hline Homarus vulgaris & 7.80 & 5.6 & 0.26 & $\mathrm{a}$ & 8 & 15 & sW & A & [57] \\
\hline Homarus gammarus & 7.78 & 9.3 & 0.44 & $\mathrm{a}$ & 15 & 15 & SW & A & [65] \\
\hline Palaemon elegans & 7.89 & $5.4^{\#}$ & 0.17 & $\mathrm{a}$ & 16 & 15 & sW & $A$ & [59] \\
\hline Palaemon adspersus & 7.85 & $4-7$ & 0.25 & $\mathrm{a}$ & $4-9$ & 15 & sW & A & [68] \\
\hline Penaeus japonicus & 7.58 & 6.0 & 0.44 & $\mathrm{a}$ & & 18 & sW & A & [52] \\
\hline Carcinus maenas & 7.82 & 3.9 & 0.15 & $\mathrm{v}$ & 13.3 & 15 & sW & $x$ & [66] \\
\hline Callinectes sapidus & 7.96 & 8.8 & 0.40 & $\mathrm{v}$ & 5 & 22 & $\mathrm{FW}$ & A & [50] \\
\hline Scylla serrata & 7.68 & $7.5^{\#}$ & 0.48 & $\mathrm{a}$ & 13.2 & 25 & SW & A & [67] \\
\hline Necora puber & 7.90 & 6.6 & 0.19 & $\mathrm{v}$ & & 15 & sW & A & [62] \\
\hline Cancer magister & 7.73 & 4.5 & 0.25 & $\mathrm{a}$ & & 17 & sW & A & [56] \\
\hline Cancer productus & 7.89 & 9.0 & 0.30 & $\mathrm{a}$ & & 10 & sW & A & [53] \\
\hline Gecarcinus lateralis & 7.37 & 5.9 & 0.86 & $\mathrm{a}$ & & 25 & SW & $\mathrm{T}$ & [63] \\
\hline Cardisoma carnifex & 7.64 & $10.3^{\#}$ & 0.93 & $\mathrm{a}$ & & 28 & SW & $\mathrm{T}$ & {$[51]$} \\
\hline
\end{tabular}


Table 3: Acid-base status in Crustacea. (Continued)

\begin{tabular}{|c|c|c|c|c|c|c|c|c|c|}
\hline Cyclograpsus lavauxi & 7.92 & 10.9 & 0.31 & $\mathrm{a}$ & & 10 & SW & $\mathrm{x}$ & [55] \\
\hline Leptograpsus variegatus & 7.90 & $5.4^{\#}$ & 0.24 & $\mathrm{a}$ & & 20 & SW & $x$ & [58] \\
\hline Holthusiana transversa & 7.33 & 9.5 & 0.80 & $\mathrm{a}$ & & 25 & $\mathrm{FW}$ & $x$ & [54] \\
\hline \multicolumn{10}{|l|}{ Amphipoda } \\
\hline Gammarus pulex & 8.00 & 12.4 & 0.40 & a & 2.6 & 12 & $\mathrm{FW}$ & A & [60] \\
\hline Gammarus fossarum & 8.00 & 10.4 & 0.33 & $\mathrm{a}$ & 3.0 & 12 & FW & A & {$[60]$} \\
\hline
\end{tabular}

Hemolymph acid-base status of various crustaceans in freshwater (FW) and seawater (SW) under aerated conditions at temperature $T$. Postbranchial $(\mathrm{a}=$ 'arterial') hemolymph was drawn from the pericardial sinus, whereas prebranchial $(v=$ 'venous') samples were taken from the infrabranchial sinus at the base of the walking leg. For each species, the typical mode of life $(A=$ aquatic, $T=$ terrestrial, $X=$ amphibious $)$ is indicated. \#total $\mathrm{CO}_{2}$, Sthis study, \$unpublished data.

was virtually the same as that of the control group. In contrast, pH 5.5 animals had a significantly lower extracellular $P_{\mathrm{CO} 2}$ of $0.33 \pm 0.04 \mathrm{kPa}$ (Table 2).

The slight acidosis in the extracellular fluid was associated with a significant $(30-65 \%)$ reduction in hemolymph bicarbonate concentration to $14.6 \pm 0.5 \mathrm{mM}$ in $\mathrm{pH} 6.0$ animals and $7.2 \pm 0.9 \mathrm{mM}$ in pH 5.5 animals (Table 2 and Figure 1A, gray and black triangles). Reductions of similar relative magnitude have been observed in freshwater crayfish [77-79]. This depletion in hemolymph bicarbonate, by the entry of acidic equivalents from the ambient medium (see below), caused a proportional reduction in the bicarbonate buffer value $\left(\beta_{\mathrm{B}}\right)$. The $\mathrm{pH} 6.0$ animals partly compensated the $30 \%$ reduction in $\beta_{\mathrm{B}}$ by increasing the non-bicarbonate buffer value $\left(\beta_{\mathrm{A}}\right)$ from 2.0 to $5.1 \mathrm{meq}$ $\mathrm{L}^{-1} \mathrm{pH}^{-1}$, while $\mathrm{pH} 5.5$ animals experienced a $65 \%$ loss in $\beta_{\mathrm{B}}$ (Table 2). Although the compensatory increase in $\beta_{\mathrm{A}}$ was almost negligible, the pH 5.5 animals still had significant reserves in $\beta_{\mathrm{A}}$ which are available in the case of a progressive acidosis (Figure 1B).

Heart rate $\left(f_{\mathrm{H}}\right)$, ventilation rate $\left(f_{\mathrm{A}}\right)$, and oxygen consumption rate $\left(\dot{M}_{\mathrm{O}_{2}}\right)$ were additionally monitored as diagnostic indicators for the mechanistic interpretation of acidbase disturbances. Compared to the control group, animals raised and tested under $\mathrm{pH} 6.0$ showed a $20 \%$ higher $f_{\mathrm{H}^{\prime}}$ a $14 \%$ higher $f_{\mathrm{A}}$ and a $38 \%$ higher $\dot{M}_{\mathrm{O}_{2}}$ (Table 2), supposedly to meet the increased maintenance requirements for ion regulation. These systemic adjustments had no influence on extracellular $P_{\mathrm{CO} 2}$. The acidosis of the $\mathrm{pH} 6.0$ animals $(\Delta \mathrm{pH}=-0.16$ units; Table 2$)$ was therefore of metabolic rather than of respiratory origin. In agreement with the convention in acid-stress physiology [80], the term 'metabolic acidosis' is used here irrespective of whether the protons originate endogenously in connection with lactic acid production or exogenously, by the influx of $\mathrm{H}^{+}$ down the large medium-to-hemolymph $\mathrm{H}^{+}$gradient. The metabolic acidosis was very likely caused by an influx of acidic equivalents from the ambient medium, since the sustained circulation and ventilation argue against the possibility of an activation of anaerobic support mechanisms.

Compared to the control group, the pH 5.5 animals experienced a 0.23 -unit decrease in extracellular $\mathrm{pH}$ (Table 2), which can be characterized as metabolic acidosis with respiratory compensation as indicated by the reduced extracellular $P_{\mathrm{CO} 2}$. Since the oxygen consumption rate (and consequently the $\mathrm{CO}_{2}$ production rate) did not change significantly in comparison to the control animals (Table $2)$, the main reasons for the reduced extracellular $P_{\mathrm{CO} 2}$ are the $34-46 \%$ increased ventilation and perfusion rates (Table 2) as well as an enhanced permeability of the integument for respiratory gases, probably due to a thinner carapace. The latter explanation is consistent with the observation of the softer carapaces, which occurred only in the pH 5.5 animals. As in acid-stressed freshwater crayfish [81-83], the softer (jelly-like) carapace of pH 5.5 animals may indicate a poor calcification resulting from exoskeletal $\mathrm{CaCO}_{3}$ erosion and reduced calcium and basic equivalent ( $\mathrm{HCO}_{3}^{-}$) uptake during the postmoult stage.

One may wonder why the acidification-induced increase in $\dot{M}_{\mathrm{O}_{2}}$ was only present in the pH 6.0 animals but absent in the pH 5.5 animals. The $\dot{\mathrm{M}}_{\mathrm{O}_{2}}$ is expressed here as specific rate $\left(\mathrm{nmol} \mathrm{h} \mathrm{h}^{-1} \mathrm{~mm}^{-3}\right.$ ), which is normalized to cubic body length rather than to body weight. It is common practice to estimate the body weight of daphnids from body length using scaling relationships (e.g. [84]). 
However, we discarded this estimation because of the uncertainty about the influence of acidification on the relationship between body length and body weight. In the pH 5.5 animals, a reduction in the amount of metabolically active biomass (per cubic body length) could have masked the supposed extra costs for ion regulation. Evidence for this explanation comes from the comparison of brood sizes of those animals which were analyzed in the respiration experiment. The egg numbers of $\mathrm{pH} 5.5$ animals $(1.2 \pm 0.6$, range: $0-6, N=12)$ were significantly lower than those of the $\mathrm{pH} 6.0$ animals $(9.1 \pm 0.6, N=12)$ and pH 7.8 animals $(7.8 \pm 1.0, N=9)$ (Kruskal-Wallis test, $P<0.001)$. All eggs were of early developmental stage and accounted for very little respiration in the brooding females [85]. Nevertheless, the reduced allocation of resources into reproduction implies an acidificationinduced disturbance in the energy and mass budgets of the $\mathrm{pH} 5.5$ animals. Indeed, these animals showed the highest degree of transparency owing to the decreased appearance of orange-colored fat cells. Fat cells store carbohydrates and lipids [86-88], the latter in form of droplets which are usually colored, owing to the presence of carotinoids [89]. In addition, fat cells produce hemoglobin [90] and are supposed to be involved in vitellogenin synthesis [91]. Whether the acidification-induced disturbance in the energy and mass budgets results solely from the increased maintenance costs for ion homeostasis or, additionally, from a reduced assimilation rate (e.g. due suboptimal $\mathrm{pH}$ conditions for enzymatic digestion of food in the gut) needs further investigation.

It is important to note that no diapausing eggs occurred in pH 5.5 animals during the six-month experimental period. Obviously, the physiologically demanding condition of pH 5.5 was either not associated with an activation of the stress-signaling cascade responsible for production of male offspring $[92,93]$ or males did not survive until maturity. The pH 6.0 animals, in contrast, were distinguished by the repeated occurrence of parthenogenic eggs with a white cover layer which probably resulted from a fungal infection. Although there are some reports on increased fungal parasitism in daphnids [94,95] and crayfish $[82,96]$ under various stress conditions, it remains to be clarified whether acid stress leads to an increased susceptibility of daphnids to fungal parasites [97].

\section{The role of acclimation in the tolerance to severe acid stress}

The tolerance to a short-term exposure to severe acid stress (ambient pH 3-4) was examined in the control and acidacclimated animals. The animals were initially exposed to their respective acclimation $\mathrm{pH}$ before the ambient $\mathrm{pH}$ was set to $\mathrm{pH} 4.0$ and then to $\mathrm{pH} 3.0$ (Figure 2). Upon exposure to ambient $\mathrm{pH} 4.0$, all groups experienced an

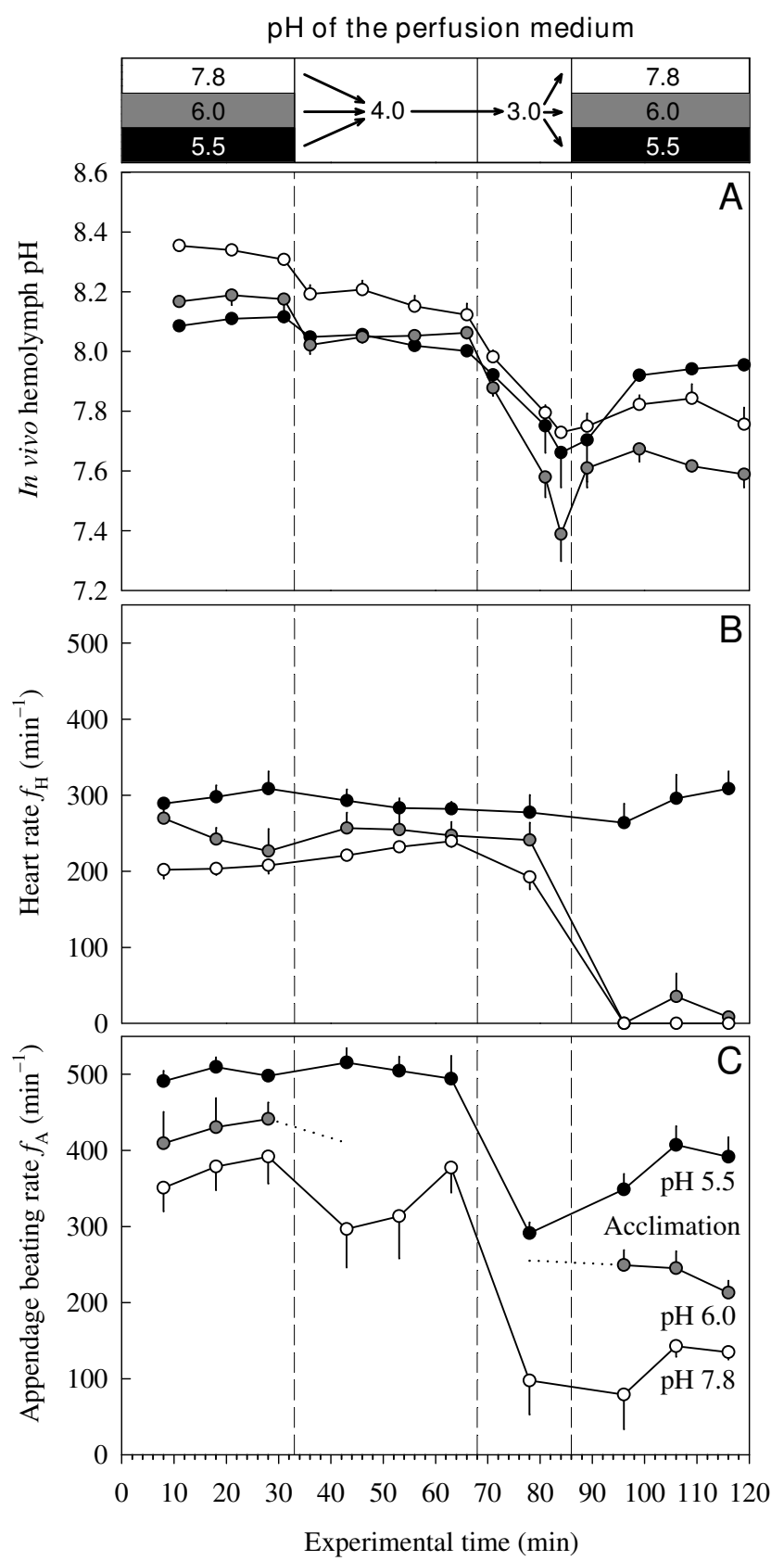

Figure 2

Tolerance to severe acid stress. Influence of ambient $\mathrm{pH}$ on in vivo hemolymph $\mathrm{pH}(\mathrm{A})$, heart rate $(\mathrm{B})$ and appendage beating rate $(\mathrm{C})$ of animals acclimated to $\mathrm{pH} 7.8$ (open symbols), pH 6.0 (grey-filled symbols), and pH 5.5 (filled symbols). Data are given as means \pm S.E. $(N=3-4)$. Dotted lines indicate a period of irregular limb beating activity. Each acclimation group was exposed to its acclimation $\mathrm{pH}$ during the initial and final phases of the experiment. 
acidosis, but were able to stabilize their extracellular $\mathrm{pH}$ at a level $0.1-0.2 \mathrm{pH}$ units below the respective pre-exposure value (Figure $2 \mathrm{~A}$ ). This response was caused by a 'metabolic acid load' of $7.0 \mathrm{meq} \mathrm{L}^{-1}$ (pH 7.8 animals), $4.5 \mathrm{meq}$ $\mathrm{L}^{-1}$ (pH 6.0 animals), and 1.3 meq L L $^{-1}$ (pH 5.5 animals). While the $f_{\mathrm{H}}$ remained unaffected in all groups (Figure $2 \mathrm{~B}$ ), diverging responses were found in $f_{\mathrm{A}}$ (Figure 2C). The $f_{\mathrm{A}}$ response spectrum comprised a transient depression in pH 7.8 animals, an irregular beating behavior in $\mathrm{pH} 6.0$ animals, and a sustained beating activity in $\mathrm{pH} 5.5$ animals.

During the subsequent 18-min exposure to ambient $\mathrm{pH}$ 3.0, the $\mathrm{pH}$ homeostasis collapsed in all acclimation groups. The extracellular $\mathrm{pH}$ showed a progressive decline (Figure 2A), which corresponded to a net flux of acidic equivalents from the ambient medium into the hemolymph of 32 meq L $^{-1} \mathrm{~h}^{-1}$ (pH 7.8 animals), 46 meq $\mathrm{L}^{-1} \mathrm{~h}^{-1}$ (pH 6.0 animals), and 16 meq $\mathrm{L}^{-1} \mathrm{~h}^{-1}$ (pH 5.5 animals). This massive net influx of acidic equivalents is in line with reports on the breakdown of ion regulation $[34,35,98,99]$. In D. magna, severe acid stress resulted in a $60-70 \%$ inhibition of the unidirectional sodium influx and a $130 \%$ increase in sodium outflux [34]. Within one hour, these animals lost $30-50 \%$ of their body sodium. The whole-body sodium concentration of D. magna is 26$41 \mathrm{mmol}$ (kg wet mass) ${ }^{-1}[35,98,100,101]$, assuming a wet-to-dry mass ratio of 10:1 [102]. This whole-body concentration is consistent with a hemolymph concentration of $65 \mathrm{mM}$ sodium [103], taking into account that the hemolymph comprises $60 \%$ of the body volume [102] and that the extracellular fluid contains the main portion of whole-body sodium. The estimated net efflux of sodium (20-30 $\left.\mathrm{mmol} \mathrm{L}^{-1} \mathrm{~h}^{-1}\right)$ from the hemolymph of $D$. magna compares well with the net influx of acidic equivalents into the hemolymph of $D$. pulex $\left(32 \mathrm{meq} \mathrm{L}^{-1} \mathrm{~h}^{-1}\right.$ in control animals). This shows that the disturbance in acidbase balance mirrors the disturbance in ion regulation and vice versa.

During the exposure to ambient $\mathrm{pH}$ 3.0, the $f_{\mathrm{A}}$ decreased strongly in all groups, whereas $f_{\mathrm{H}}$ remained apparently unaffected (Figure 2B, C). However, the subsequent recovery period revealed a (somewhat delayed) heart arrest and a deformation of heart structure in the $\mathrm{pH} 7.8$ and $\mathrm{pH} 6.0$ animals. Their extracellular $\mathrm{pH}$ values during the recovery period remained $0.55 \mathrm{pH}$ units below initial (pre-acid exposure) values. The pH 5.5 animals, in contrast, were able to reduce the difference between the pre- and postexposure values to 0.16 units. This was the only group which survived the severe-acid test.

Of all acclimation groups, the pH 5.5 animals had the highest tolerance to severe acid stress as indicated by the lowest net influx of acidic equivalents $\left(16 \mathrm{meq} \mathrm{L}^{-1} \mathrm{~h}^{-1}\right)$.
This implies a lower disturbance of extracellular ion regulation in the pH 5.5 animals compared to the other two acclimation groups, which may explain the unique ability to sustain heart-beating activity in the former and heart arrest in the latter. The results of the severe-acid test further suggest that the acclimation to ambient $\mathrm{pH} 5.5$ induced a compensatory increase in active ion transport and/or a reduction in the epithelial permeability for sodium and hydrogen ions. However, the suggested reduction in epithelial ion permeability contrasts with the increased integumental permeability for respiratory gases arising from the impaired carapace formation. It therefore seems that active compensation in ion transport is the more likely defence mechanism.

\section{Interdependence between acid-base balance and $\mathrm{CO}_{2}$ transport}

Information on extracellular $\mathrm{pH}$ in the heart region and on hemolymph bicarbonate concentration made it possible to determine the local $P_{\mathrm{CO} 2}$ in the pericardial hemolymph. In daphnids, the pericardial space receives hemolymph from the carapace lacuna, which is an important site of gas exchange $[36,76]$, and from the dorsal lacuna, which is fed by the current leaving the intestinal lacuna [36]. In the carapace lacuna, the $P_{\mathrm{CO} 2}$ is low due to the transintegumental diffusion of $\mathrm{CO}_{2}$ from the hemolymph into the ambient medium. In the intestinal lacuna (which traverses the body core region), the $P_{\mathrm{CO} 2}$ is high because metabolically produced $\mathrm{CO}_{2}$ is released into the hemolymph. The local $P_{\mathrm{CO} 2}$ in the pericardial space therefore assumes an intermediate value that lies between the two $P_{\mathrm{CO} 2}$ extremes. The magnitude of the $P_{\mathrm{CO} 2}$ differences in the circulatory system strongly depends on the presence or absence of a carbonic anhydrase (CA). In the absence of a CA, the interconversion between $\mathrm{CO}_{2}$ and $\mathrm{HCO}_{3}^{-}$ proceeds slowly [104]. For example, a $25 \mathrm{mM}$ bicarbonate solution with a non-bicarbonate buffer value of 2-10 meq $\mathrm{L}^{-1} \mathrm{pH}^{-1}$ needs $3-12 \mathrm{~s}$ for a half-change in hydrogen concentration following the abrupt increase in $P_{\mathrm{CO} 2}$ from 5 to $11 \mathrm{kPa}$ [105]. These half-equilibration times apply to $37^{\circ} \mathrm{C}$, so even longer would be needed at $20^{\circ} \mathrm{C}$. Given a hemolymph circulation time of $21 \mathrm{~s}$ in a $2.5 \mathrm{~mm} D$. magna at $20^{\circ} \mathrm{C}$ (cardiac output: $32 \mathrm{nl} \mathrm{s}^{-1}$ [74], hemolymph volume: $680 \mathrm{nl}$ [102], it is clear that hemolymph passage time from the tissues to the respiratory surfaces is too short to bring the uncatalyzed $\mathrm{CO}_{2}+\mathrm{H}_{2} \mathrm{O} \leftrightarrow \mathrm{H}^{+}+\mathrm{HCO}_{3}^{-}$ reaction into full equilibrium. Under these circumstances, the main share of metabolically produced $\mathrm{CO}_{2}$ would be transported as physically dissolved gas rather than in the 

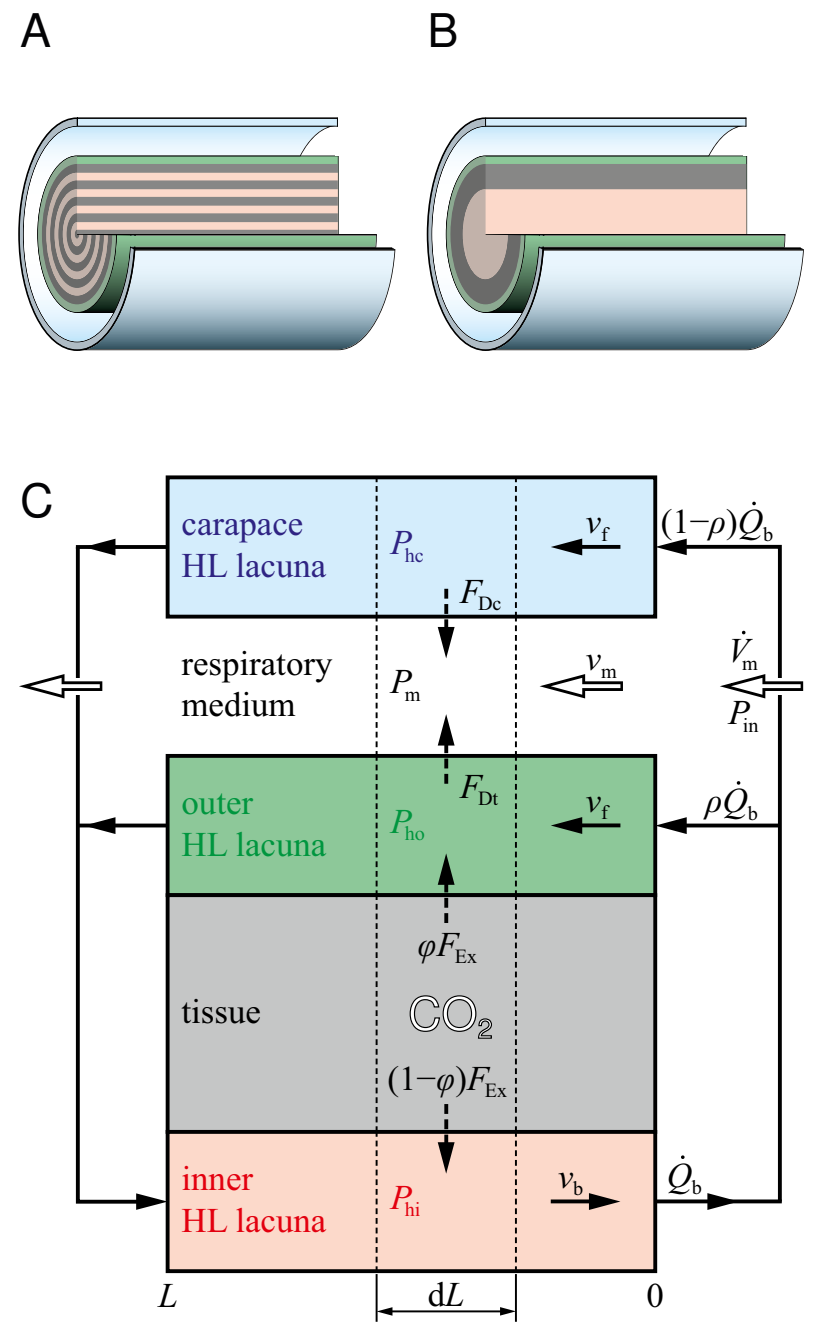

Position along the exchange coordinate
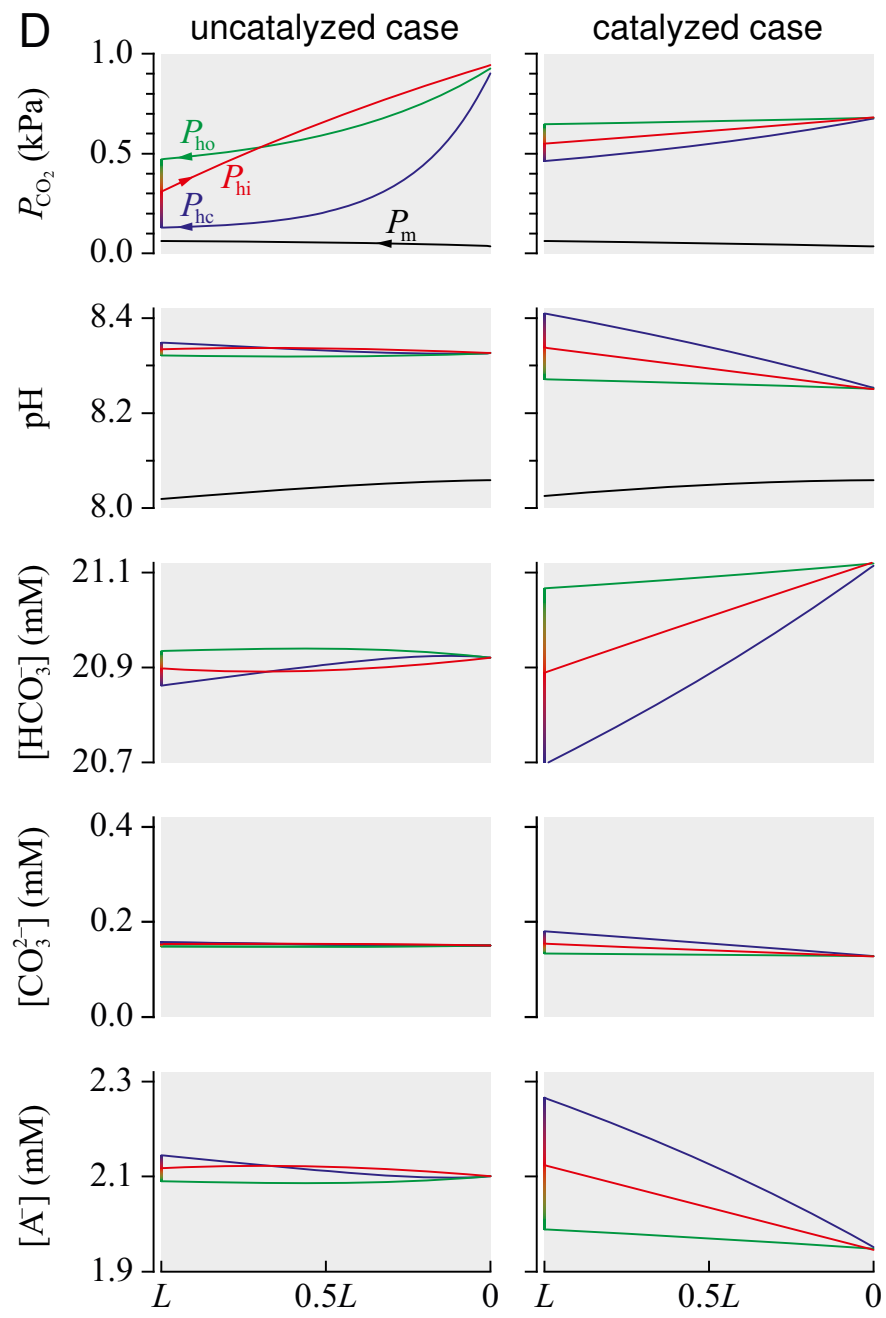

Position along the exchange coordinate

\section{Figure 3}

Modelling and simulation of $\mathrm{CO}_{2}$ transport. (A) Reference topology based on a cylinder-within-tubes arrangement ( $\mathrm{R}$.

Moenickes, $\mathrm{O}$. Richter and R. Pirow, in preparation). A sector piece was removed to show the alternation of concentric hollow cylinders of tissue (gray) and hemolymph (red, green, blue). (B) Simplified topology with only one tissue layer. This topology is applied in the compartment model. (C) Compartment model of the relevant transport processes. $\mathrm{CO}_{2}$ is excreted from the tissue compartment of length $\mathrm{d} L$ into the inner and outer hemolymph $(\mathrm{HL})$ lacuna at rates of $(\mathrm{I}-\phi) \mathrm{F}_{\mathrm{Ex}}$ and $\phi \mathrm{F}_{\mathrm{Ex}}$. Hemolymph leaving the inner $\mathrm{HL}$ lacuna at a volume-flow rate $\dot{Q}_{\mathrm{b}}$ is distributed between the outer $\mathrm{HL}$ lacuna and the carapace $\mathrm{HL}$ lacuna. From these compartments $\mathrm{CO}_{2}$ diffuses across cuticular barriers into the medium, which flows at a rate of $\dot{V}_{\mathrm{m}}$. Indicated are the $\mathrm{CO}_{2}$ partial pressures $\left(P_{\mathrm{hi}}, P_{\mathrm{ho}}, P_{\mathrm{hc}}, P_{\mathrm{m}}\right)$ and flow velocities $\left(v_{\mathrm{b}}, v_{\mathrm{f}}, v_{\mathrm{m}}\right)$ in the hemolymph lacunae and the medium. $P_{\text {in }}$ is the inspiratory $P_{\mathrm{CO} 2}$ (D) Simulation results for the uncatalyzed and catalyzed hydration of $\mathrm{CO}_{2}$ for an animal exposed to normal conditions (ambient $\mathrm{pH}=8.0$, ambient $P_{\mathrm{CO} 2}=0.035 \mathrm{kPa}$ ). Acid-base variables are shown for the medium and hemolymph lacunae in relation to the exchange coordinate. 
chemically combined form as bicarbonate with the consequence of relatively large $P_{\mathrm{CO} 2}$ differences between the loading and unloading sites.

Knowledge about the presence or absence of a CA in the circulatory fluid is therefore fundamental for the understanding of $\mathrm{CO}_{2}$ transport and acid-base balance in daphnids. The reported absence of CA activity in the hemolymph of decapod crustaceans [106-109] prompted us to analyse the physiological implications of circulatory $\mathrm{CO}_{2}$ transport under uncatalyzed conditions in more detail. Based on established concepts of compartment modelling $[110,111]$ and on own experiences in the simulation of whole-animal oxygen transport in daphnids $[71,112]$, we derived a multi-compartment model of the $\mathrm{CO}_{2}$ diffusion-convection-reaction system (Figure 3C) to simulate the transport of $\mathrm{CO}_{2}$ from the tissue via the hemolymph to the ambient medium. To obtain a $\mathrm{pH}$ of 8.334 at the entrance of the inner hemolymph lacuna (Figure 3C), the Krogh constant for the diffusion of $\mathrm{CO}_{2}$ in chitin $(K)$ was set to $2.10 \times 10^{-6} \mathrm{nmol} \mathrm{s}^{-1} \mathrm{~mm}^{-1} \mathrm{kPa}^{-1}$. To our knowledge, there are no experimental data in the literature on Krogh's diffusion constant for $\mathrm{CO}_{2}$ in chitin. Nevertheless, the chosen $K$ value is plausible insofar as it is of the same order of magnitude as Krogh's diffusion constant for $\mathrm{O}_{2}$ in chitin $\left(0.95 \times 10^{-6} \mathrm{nmol} \mathrm{s}^{-1} \mathrm{~mm}^{-1} \mathrm{kPa}^{-1}\right)$ [113]. The similarity in both values seems to contradict the well-known fact that Krogh's diffusion constant for $\mathrm{CO}_{2}$ in water and aqueous tissues is 20-25 times higher than that for $\mathrm{O}_{2}$, a phenomenon that is explained by the higher capacitance (solubility) coefficient of $\mathrm{CO}_{2}$ in aqueous media [114]. The cuticle of arthropods, however, is primarily composed of chitin fibers which are embedded in a more or less hydrated protein matrix [115]. Among the different layers (epicuticle, exocuticle, endocuticle), the exocuticle is relatively dehydrated [115] and may therefore establish a similar diffusion barrier for $\mathrm{O}_{2}$ and $\mathrm{CO}_{2}$.

The $\mathrm{CO}_{2}$ transport model made it possible to follow the changes in extracellular acid-base variables during a full circulation cycle (Figure 3D, uncatalyzed case). The extracellular $P_{\mathrm{CO} 2}$ in the three hemolymph compartments varies largely between $0.13-0.94 \mathrm{kPa}$, whereas the extracellular $\mathrm{pH}$ remains confined to the narrow range of $\mathrm{pH}$ 8.32-8.35. The small changes in bicarbonate concentration $(<0.01 \mathrm{mM})$ reflect the slow interconversion between $\mathrm{CO}_{2}$ and $\mathrm{HCO}_{3}^{-}$. Compared to bicarbonate, the carbonate and non-bicarbonate buffers show concentration changes in opposite direction as they are involved in the buffering of hydrogen ions arising from the hydration of $\mathrm{CO}_{2}$ and subsequent dissociation of carbonic acid.
The simulation provides a plausible prediction of the extracellular $\mathrm{CO}_{2}$ and $\mathrm{pH}$ gradients that would develop in the absence of a hemolymph CA. However, a screening of the D. pulex genome database $[116,117]$ unexpectedly revealed 31 genes with CA-like coding sequences (Table $4)$. These genes belong to two evolutionarily unrelated $C A$ gene families ( $\alpha$-CA and $\beta$-CA) [118]. The derived aminoacid sequences were aligned with selected metazoan sequences (Additional files 1 and 2) [119-122] and classified in terms of their putative destination (Figure 4A, B) [123], based on sequence features and the known localization of CAs from crab [124], mosquito [125], and man [118]. The phylogenetic analysis of $\alpha$-CA sequences showed a distinct separation between mitochondrial and cytoplasmic, CA-related, membrane-bound and transmembrane, and secretory proteins (Figure 4A). Among the $30 \alpha$-CAs from $D$. pulex were 25 sequences (CAA6A-H, CAA7A-Q) with an N-terminal signal peptide for secretory export. Seven of these putative extracellular isoforms are currently supported by EST data. So far, nothing is is known about the extracellular target sites. To account for the possibility of CA secretion into the hemolymph, we simulated a second scenario, in which a hemolymph CA accelerates the interconversion between $\mathrm{CO}_{2}$ and $\mathrm{HCO}_{3}^{-}$ by a factor of 10000 [126], which is sufficiently large to establish an equilibrium. Krogh's diffusion constant for $\mathrm{CO}_{2}$ in chitin was slightly reduced to $1.30 \times 10^{-6} \mathrm{nmol} \mathrm{s}^{-1}$ $\mathrm{mm}^{-1} \mathrm{kPa}^{-1}$ to obtain a $\mathrm{pH}$ of 8.334 at the entrance of the inner hemolymph lacuna (Figure 3C). Compared to the uncatalyzed case, the catalyzed hydration/dehydration of $\mathrm{CO}_{2}$ significantly reduced the variations in extracellular $P_{\mathrm{CO} 2}$ to the narrow range of $0.46-0.68 \mathrm{kPa}$ (Figure $3 \mathrm{D}$ ), indicating that less $\mathrm{CO}_{2}$ is transported as physically dissolved gas. Instead, more $\mathrm{CO}_{2}$ is transported in the chemically combined form as reflected by the large variation in bicarbonate concentration. Moreover, the extracellular $\mathrm{pH}$ varied substantially between the 'prebranchial' value of 8.25 (inner HL lacuna) and the 'postbranchial' value of 8.41 (carapace HL lacuna).

The two simulated scenarios represent a coherent description of the physiological implications arising from the presence or absence of a CA in the hemolymph of $D$. pulex. The selected values for the global adjustment parameter $K$ remain within reasonable bounds that made it impossible to put more weight to one of the two models. Nevertheless, the predicted extracellular $P_{\mathrm{CO} 2}$ and $\mathrm{pH}$ gradients represent a working hypothesis that will be tested in subsequent experiments. $\mathrm{pH}$ imaging tech- 


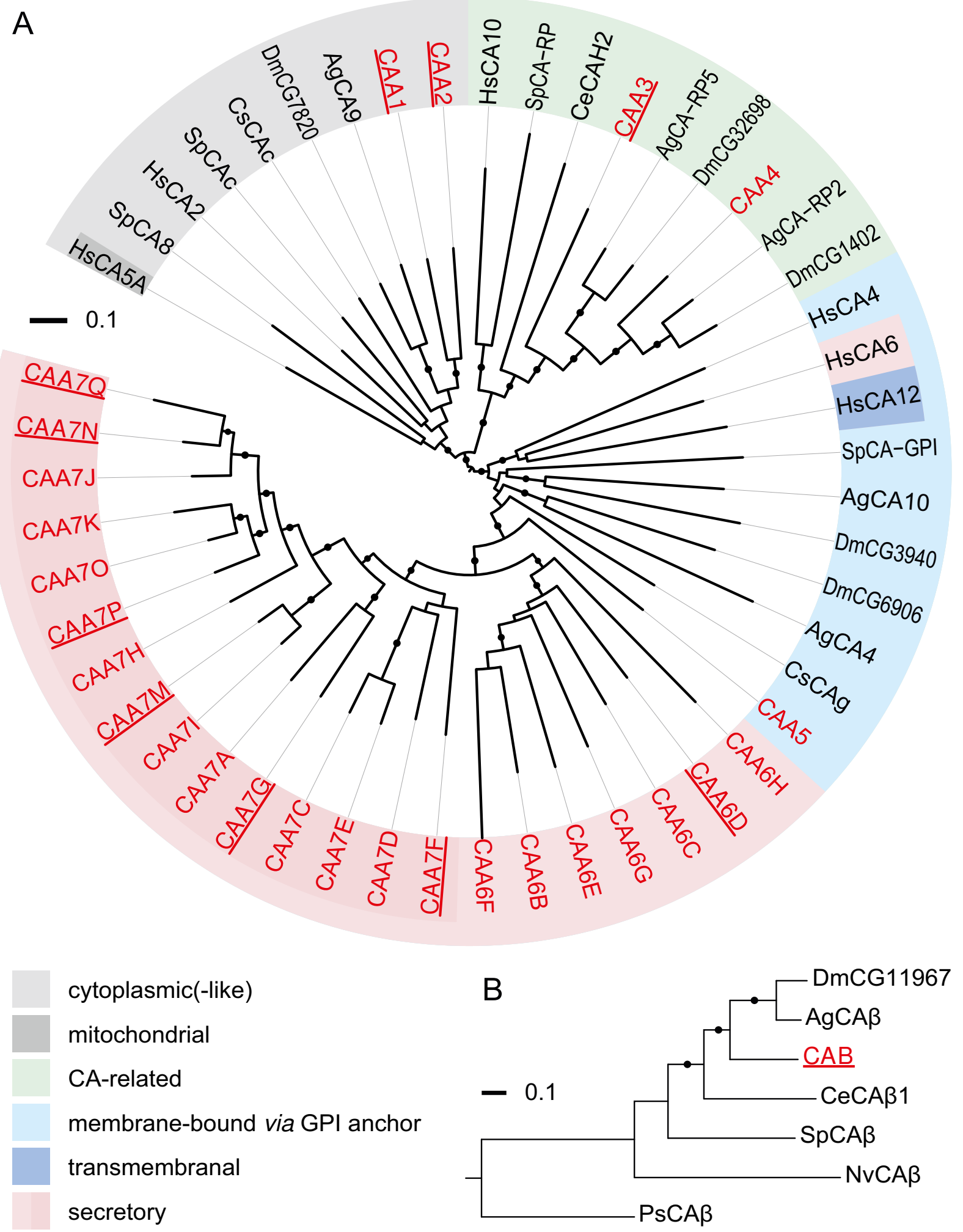

Figure 4 (see legend on next page) 
Figure 4 (see previous page)

Classification of CA-like amino acid sequences from Daphnia pulex. Phylogenetic trees for selected $\alpha$-carbonic anhydrases ( $\alpha$-CAs) $(A)$ and $\beta$-CAs $(B)$ based on multiple-sequence alignments (Additional files I and 2). D. pulex sequences are shown in red; underlined labels indicate EST support. Three fragmentary sequences (CAA6A, CAA7B, CAA7L; Table 4) from $D$. pulex were excluded from the alignment. Additionally included were related sequences from the blue crab Callinectes sapidus (Cs), Drosophila melanogaster (Dm), Anopheles gambiae (Ag), Caenorhabditis elegans (Ce), sea urchin Strongylocentrotus purpuratus $(\mathrm{Sp})$, Homo sapiens (Hs), the sea anemone Nematostella vectensis (Nv), and Pisum sativum (Ps). $\alpha$-CAs were classified in terms of their putative destination into mitochondrial and cytoplasmic, CA-related, membrane-bound and transmembrane, and secretory proteins. CA-related proteins have lost most of the highly conserved active-site residues. Membrane-associated $\alpha$-CAs have a C-terminal attachment signal for a glycosylphosphatidylinositol (GPI) anchor which tethers the extracellular protein to the cell membrane [123]. The trees were constructed using the neighbor-joining algorithm. Bootstrap analysis was performed with 1000 replicates (bootstrap values $>800$ are indicated by filled circles). For sequence references, see Additional files I and 2.

niques, for example, should have the resolution power to detect a spatial in vivo gradient as large as $0.1-0.2 \mathrm{pH}$ units to verify or falsify the assumption of CA activity in the circulatory system of D. pulex. Further in vivo experiments may include the application of a strong diffusible CA inhibitor or the microinjection of an exogenous CA [127].

\section{Conclusion}

Chronic acid exposure induced pronounced effects in extracellular $\mathrm{pH}$, bicarbonate concentration and $\mathrm{CO}_{2}$ partial pressure, as well as in circulation, ventilation and energy metabolism. Compensatory changes in extracellular non-bicarbonate buffering capacity and the improved tolerance to severe acid stress indicated the activation of defense mechanisms. The physiological changes were associated with an impairment of carapace formation and with reductions in reserve materials and reproduction. Mechanistic analyses of the interdependence between extracellular acid-base balance and $\mathrm{CO}_{2}$ transport led to the identification and classification of 31 carbonic anhydrase isoforms which are encoded in the genome of $D$. pulex. The multitude of physiological information that can be acquired from these transparent crustaceans via optical techniques underlines the great advantage of Daphnia pulex as a model system for environmental studies. Proteomic analyses are underway to identify the molecular mechanisms and target genes involved in Daphnia's responses to a variety of environmental stresses including freshwater acidification.

\section{Methods}

\section{Acclimation conditions}

Animals were raised at $20^{\circ} \mathrm{C}$ in aerated M4 medium [128] under three different $\mathrm{pH}$ conditions at a $16 \mathrm{~h}: 8 \mathrm{~h} \mathrm{~L}: \mathrm{D}$ photoperiod. The control condition $(7.8 \pm 0.2$, mean \pm variation range) was manually adjusted twice a week using $0.005 \mathrm{M} \mathrm{H}_{2} \mathrm{SO}_{4}$ and $0.01 \mathrm{M} \mathrm{NaOH}$. The $\mathrm{pH} 6.0 \pm 0.1$ condition was established by adding $5 \mathrm{mM}$ MES buffer (2morpholinoethansulfonic acid) to the medium. pH $5.5 \pm$ 0.05 was maintained by a pH-Stat, which was equipped with a pH electrode (N 6000; Schott-Geräte GmbH, Mainz, Germany) and which controlled the addition of $0.05 \mathrm{M} \mathrm{H}_{2} \mathrm{SO}_{4}$ delivered by a peristaltic pump (Gilson ABIMED, Villiers, France).

The pH 7.8 and pH 6.0 animals were cultured in 2 L glass beakers (containing 1.8 L medium) at a density of 25-50 individuals (juveniles plus adults) per vessel. The $\mathrm{pH} 5.5$ animals were kept in a $20 \mathrm{~L}$ glass aquarium (containing 8 L medium) at a density of 100-200 individuals. Surplus offspring were sorted out twice a week. Given the case of appearance, females with ephippia and males were sorted out, so that parthenogenesis and clonal reproduction was maintained. Animals were fed ad libitum with Desmodesmus subspicatus (final concentration: $15.5 \times 10^{4}$ cells per $\mathrm{ml}$ culturing medium) six times a week. To minimize the influence of algae on medium pH [129], sedimented food material was removed once (glass aquarium) or twice (glass beaker) a week. During this procedure, any algal surface buildup was removed by scrubbing the enclosures, and at least half of the medium was exchanged by fresh medium.

\section{Analysis of hemolymph buffer curves}

Hemolymph samples $(0.2-1 \mu \mathrm{l}$ per animal) were drawn as described elsewhere [73] and collected in ice-cooled $500 \mu \mathrm{l}$ reaction vials. The pooled hemolymph (30-100 $\mu \mathrm{l}$ ) was filtered (cellulose acetate syringe filters, $0.45 \mu \mathrm{m}$ pore size; Nalgene, Rochester, NY), shortly centrifuged to remove any air bubbles, and finally kept on ice. Hemolymph buffer curves were measured with a micro-pH-electrode (MI-4152; Microelectrodes Inc., Bedford, U.S.A.) in a gas diffusion chamber [130] at $20^{\circ} \mathrm{C}$. The $\mathrm{pH}$ electrode was linked to a pH-meter (MP 230, Mettler Toledo, Swiss) which transferred the data to a computer. Traceable NIST standard reference buffers ( $\mathrm{pH} 6.88$ and $\mathrm{pH} 9.23$ at $20^{\circ} \mathrm{C}$, type number: L 4798; Schott-Geräte $\mathrm{GmbH}$ ) were used for calibration. Hemolymph samples of 5-10 $\mu$ l were equilibrated with humidified gas mixtures of different $\mathrm{CO}_{2}$ partial pressure $\left(P_{\mathrm{CO} 2}=0.135-5.50 \mathrm{kPa}\right)$. The gas mixtures 
Table 4: List of referred carbonic anhydrase-like proteins and gene models from $D$. pulex.

\begin{tabular}{|c|c|c|c|}
\hline Symbol & Model name & Protein ID & Reference ID \\
\hline$C A B$ & PIR_PASA_GEN_2900003 & 347880 & 304414 \\
\hline CAAI & PIR_estExt_fgeneshI_pg.C_80063 & 442498 & 222096 \\
\hline CAA2 & PIR_estExt_fgeneshI_pg.C_80I58 & 442497 & $22214 \mid$ \\
\hline CAA3 & PIR_e_gwl.74.6.I & 442499 & 58540 \\
\hline CAA4 & PIR_e_gwl.4.553.I & 442496 & 42376 \\
\hline CAA5 & PIR_NCBI_GNO_2000I80 & 442477 & 317362 \\
\hline CAA6A & PIR_I_NCBI_GNO_040029I & 442779 & 311517 \\
\hline CAA6B & PIR_SNAP_00002730 & $44247 \mid$ & 41941 \\
\hline CAA6C & PIR_e_gwl.4.I43.I & 442472 & $4|94|$ \\
\hline CAA6D & PIR_PASA_GEN_0400293 & 442467 & 305654 \\
\hline CAA6E & PIR_NCBI_GNO_0400294 & 442475 & 311520 \\
\hline CAA6F & PIR_e_gwl.4.I54.I & 442468 & 42212 \\
\hline CAA6G & PIR_e_gwl.4.906.I & 442476 & 42004 \\
\hline CAA6H & PIR_e_gwl.4.98.I & 442478 & 42484 \\
\hline CAA7A & PIR_PASA_GEN_0400138 & 442480 & 305530 \\
\hline CAA7B & PIR_NCBI_GNO_0400455 & 442481 & 42005 \\
\hline CAA7C & PIR_SNAP_00002914 & 442482 & none \\
\hline CAA7D & PIR_SNAP_00002915 & 442483 & 42005 \\
\hline CAA7E & PIR_NCBI_GNO_0400456 & 442484 & 42005 \\
\hline CAA7F & PIR_PASA_GEN_0400354 & 442479 & 305707 \\
\hline CAA7G & PIR_PASA_GEN_360007I & 442494 & 305268 \\
\hline CAA7H & PIR_SNAP_00002923 & 442485 & 234865 \\
\hline CAA7I & PIR_NCBI_GNO_0400466 & 442486 & 42371 \\
\hline CAA7J & PIR_e_gwl.4.668.I & 442487 & 42371 \\
\hline CAA7K & PIR_SNAP_00002925 & 442488 & 234867 \\
\hline CAA7L & PIR_SNAP_00002926 & 442489 & 234868 \\
\hline CAA7M & PIR_NCBI_GNO_0400472 & 442491 & 221343 \\
\hline CAA7N & PIR_estExt_fgeneshI_pg.C_40469 & 442490 & 221343 \\
\hline
\end{tabular}


Table 4: List of referred carbonic anhydrase-like proteins and gene models from $D$. pulex. (Continued)

\begin{tabular}{|c|c|c|c|}
\hline CAA7O & PIR_NCBI_GNO_0400474 & 442492 & 311700 \\
\hline CAA7P & PIR_estExt_Genewise I.C_40740 & 442493 & $20708 I$ \\
\hline CAA7Q & PIR_estExt_fgenesh I_Pg.C_400I46 & 442495 & 225703 \\
\hline
\end{tabular}

Given are the protein names, gene model names and protein identification numbers of those loci which were annotated in the present study. Protein IDs indicate manually curated gene models that may differ from those contained in the 'Filtered Models vI. I' set (released by JGI in July 2007) [II7]. The Reference ID can be used to retrieve the corresponding models from the Filtered Models set vI.I.

were prepared from highly pure nitrogen (> 99.996\%) and carbon dioxide (99.995\%; Air Liquide, Düsseldorf, Germany) using a gas mixing pump (2 M 303/a-F Wösthoff oHG Bochum, Germany).

For analysis, the hemolymph of Daphnia was considered as a binary buffer system consisting of the carbonate system and a monoprotic non-bicarbonate buffer $\left(\mathrm{HA} \leftrightarrow \mathrm{H}^{+}\right.$ $\left.+\mathrm{A}^{-}\right)$. The dependence of $\mathrm{pH}$ on $P_{\mathrm{CO} 2}$ for such a system is described by the following balance equation [131]

$0=\alpha_{\mathrm{CO}_{2}} P_{\mathrm{CO}_{2}}\left(\frac{K_{1}^{\prime}}{\left\{\mathrm{H}^{+}\right\}}+\frac{2 K_{1}^{\prime} K_{2}^{\prime}}{\left\{\mathrm{H}^{+}\right\}^{2}}\right)+\frac{K_{\mathrm{W}}^{\prime}}{\left\{\mathrm{H}^{+}\right\}}+\frac{C_{\mathrm{A}}}{\left\{\mathrm{H}^{+}\right\} / K_{\mathrm{A}}^{\prime}+1}-\left\{\mathrm{H}^{+}\right\}-\mathrm{SID}$,

where $\left\{\mathrm{H}^{+}\right\}$is $10^{-\mathrm{pH}}, K_{\mathrm{w}}^{\prime}\left(=10^{-14} \mathrm{M}\right)$ is the dissociation equilibrium constant of water, and SID represents the strong ion difference [132]. $C_{\mathrm{A}}$ and $K_{\mathrm{A}}^{\prime}$ are the concentration and dissociation equilibrium constants of the nonbicarbonate buffer, whereas $K^{\prime}{ }_{1}$ and $K^{\prime}{ }_{2}$ represent the first and second dissociation equilibrium constants of the carbonate system. The physical solubility of $\mathrm{CO}_{2}$ in hemol-

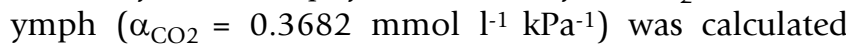
according to a thermodynamic model $[133,134]$, assuming a sodium concentration of $58 \mathrm{mM}$ and a solution density of $1 \mathrm{~g} \mathrm{l}^{-1}$. Operational $\mathrm{pK}^{\prime}$-values of the carbonate system $\left(\mathrm{pK}^{\prime}{ }_{1}=6.325 \pm 0.002, \mathrm{pK}_{2}{ }_{2}=10.47 \pm 0.09\right.$; means \pm S.E.) were determined from standard bicarbonate solutions $(4,8,16 \mathrm{mM} \mathrm{NaHCO}$ plus $50 \mathrm{mM} \mathrm{NaCl})$ using three equilibration steps $\left(P_{\mathrm{CO} 2}=0.13,0.50,2.0 \mathrm{kPa}\right)$ (Additional file 3). These standard bicarbonate solutions were a valid representation of Daphnia hemolymph in terms of ionic strength which, besides protein concentration, affects the $\alpha_{\mathrm{CO} 2}$ and the $\mathrm{p} K^{\prime}$-values [131]. The influence of protein concentration on $\alpha_{\mathrm{CO} 2}$ was negligible because the proteins in Daphnia hemolymph occupy less than $1 \%$ of hemolymph volume.

Given the $P_{\mathrm{CO} 2}$-pH data, parameter values for SID, $C_{\mathrm{A}}$ and $K_{\mathrm{A}}$ were obtained by nonlinear least-squares data fitting. The analytical procedure additionally contained a correction for incomplete hemolymph equilibration at the lowest $P_{\mathrm{CO} 2}$ step (Additional file 3 ). The concentrations of bicarbonate and carbonate are given by

$$
\left[\mathrm{HCO}_{3}^{-}\right]=\alpha_{\mathrm{CO}_{2}} P_{\mathrm{CO}_{2}} 10^{\mathrm{pH}-\mathrm{p} K_{1}^{\prime}}
$$

and

$$
\left[\mathrm{CO}_{3}^{2-}\right]=\left[\mathrm{HCO}_{3}^{-}\right] \cdot 10^{\mathrm{pH}-\mathrm{p} K_{2}^{\prime}} .
$$

The appropriateness of the operational parameter values for the calculation of bicarbonate was validated by the direct measurement of total $\mathrm{CO}_{2}$ in Triops cancriformis hemolymph (R. Pirow, unpublished data), whose ionic strength is comparable to that of Daphnia hemolymph. The non-bicarbonate buffer value $\left(\beta_{\mathrm{A}}\right)$ was obtained from $[131,135]$

$$
\beta_{\mathrm{A}}=\ln 10 \cdot \mathrm{C}_{\mathrm{A}} \frac{K_{\mathrm{A}}^{\prime}\left\{\mathrm{H}^{+}\right\}}{\left(K_{\mathrm{A}}^{\prime}+\left\{\mathrm{H}^{+}\right\}\right)^{2}} .
$$

The buffer values of bicarbonate $\left(\beta_{\mathrm{B}}\right)$ and carbonate $\left(\beta_{\mathrm{C}}\right)$ were determined for the open-system condition $[135,136]$, under which the hemolymph $P_{\mathrm{CO} 2}$ is assumed to be held constant in vivo (as by the control of ventilation) [136]:

$$
\beta_{\mathrm{B}}=\ln 10 \cdot\left[\mathrm{HCO}_{3}^{-}\right]
$$

and

$$
\beta_{\mathrm{C}}=2 \cdot \ln 10 \cdot\left[\mathrm{CO}_{3}^{2-}\right]
$$

Finally, the concentration of acidic equivalents added to the hemolymph $\left(\Delta \mathrm{H}^{+}\right.$, 'metabolic acid load') [78] during acute exposure to severe acid stress was obtained from

$$
\Delta \mathrm{H}^{+}=\left[\mathrm{HCO}_{3}^{-}\right]_{1}-\left[\mathrm{HCO}_{3}^{-}\right]_{2}+[\mathrm{HA}]_{2}-[\mathrm{HA}]_{1}
$$

where the subindices 1 and 2 refer to the concentrations before and during the exposure.

\section{Microfluorometric set-up}

Fluorescence measurements were performed with an inverted microscope (Axiovert 10, Carl Zeiss, Oberkochen, Germany) equipped with a monochromatic illumi- 
nation system (T.I.L.L. Photonics, Planegg, Germany) and an imaging spectrograph (SpectraPro-275I, Acton Research Corporation, Acton, MA, USA). A $10 \times$ objective (Plan Neofluar, Zeiss) was used for all experiments. The fluorescence light was transmitted by a quartz fibre-optic light guide to the imaging spectrograph, which was equipped with a thermoelectrically-cooled $\left(-10^{\circ} \mathrm{C}\right) \mathrm{CCD}$ camera (HLS 1024/64bi; Proscan elektronische Systeme $\mathrm{GmbH}$, Lagerfeld, Germany) containing a highly-sensitive (back-thinned), 16-bit CCD chip (1024 × 58 pixels; S7031-1006, Hamamatsu Photonics, Herrsching am Ammersee, Germany). A CCD exposure time of 2 min was used for spectrum acquisition. Fluorescence emission spectra were smoothed with a span of $30 \mathrm{~nm}$.

\section{Calibration of cSNARF-I}

A stock solution of 70-kDa dextran-coupled cSNARF-1 (D-3304, Molecular Probes, Inc., Oregon, USA) was prepared by dissolving $5 \mathrm{mg}$ lyophilized dye in $250 \mu \mathrm{l}$ sterilefiltered Milli-Q water (Millipore, Schwalbach, Germany). The stock solution was 1:20 diluted with a $10 \mathrm{mM}$ $\mathrm{NaHCO}_{3}$ solution containing $50 \mathrm{mM} \mathrm{NaCl}$. Given a conjugation ratio of 3-8 chromophore groups per dextran particle (Molecular Probes product information, 2003), the average concentration of CSNARF-1 in the calibration solution was $80 \mu \mathrm{M}$. Using the diffusion chamber and the microfluorometric set-up described above, a $10 \mu \mathrm{l}$ sample was equilibrated with gas mixtures of different $P_{\mathrm{CO} 2}$ $(0.135-5.50 \mathrm{kPa})$. At the end of each equilibration step, a fluorescence spectrum and the sample $\mathrm{pH}$ were measured.

The $\mathrm{CO}_{2}$ titration of a bicarbonate-buffered cSNARF-1 solution containing additionally $50 \mathrm{mM} \mathrm{NaCl}$ had the advantage of calibrating the $\mathrm{pH}$-sensitive dye in a chemical environment whose ionic composition is similar to that of Daphnia hemolymph (see Discussion). However, the chosen $\mathrm{CO}_{2}$ partial pressures were not sufficient to achieve $\mathrm{pH}$ extremes which could shift the dye into the fully protonated (acid) and deprotonated (base) forms (Figure 5A). Reiterative least-squares spectral resolution (Additional file 4) [137] was therefore employed to recover the spectra of the acid/base forms (Figure 5B) and the $\mathrm{p} K_{\mathrm{a}}^{\prime}$ value of cSNARF-1. The calibration yielded a $\mathrm{p} K_{\mathrm{a}}^{\prime}$ of 7.624 (Figure 5D).

\section{In vivo measurements}

Adult females with a carapace length of 1.9-2.6 mm and parthenogenetic embryos of developmental stage 2 [138] were used. Animals were immobilized as described [73]. For cSNARF-1 microinjection, small glass capillaries (GB 120 F10, Science Products GmbH, Hofheim, Germany) were thinly drawn out with a micropipette puller (model 77; Sutter Instruments, Novato, CA, USA). $2 \mu \mathrm{l}$ cSNARF-1 stock solution $(1.57 \mathrm{mM})$ were loaded into the micropipette. The solution was microinjected (Transjector 5246;
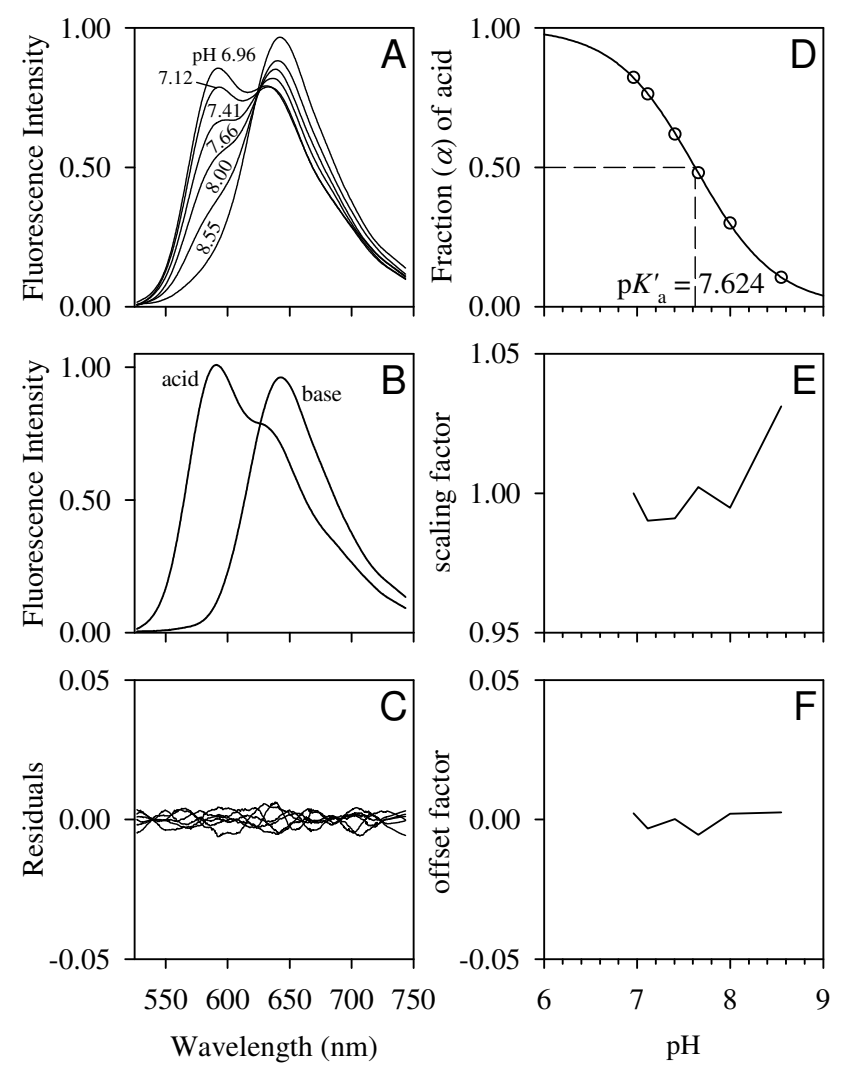

Figure 5

Calibration of cSNARF-I. Fluorescence emission spectra of a bicarbonate-buffered cSNARF-I solution were acquired at various $\mathrm{pH}$ values $(\mathrm{A})$. Fluorescence excitation was at 475 $\mathrm{nm}$. Reiterative least-squares spectral resolution [137] (Additional file 4) was applied to the data to extract the spectra of the acid/base forms (B) and the $\mathrm{pK}_{\mathrm{a}}^{\prime}$ value of cSNARF-I. The underlying model that relates the fraction of acid $\alpha$ to $\mathrm{pH}$ (D) is given by $\alpha=\left\{\mathrm{H}^{+}\right\} /\left(\mathrm{K}_{\mathrm{a}}^{\prime}+\left\{\mathrm{H}^{+}\right\}\right)$. The optimum $\mathrm{pK}_{\mathrm{A}}^{\prime}$ value of 7.624 was reiteratively obtained by using the Nelder-Mead simplex algorithm [144]. The inclusion of an additive offset factor $(E)$ and multiplicative scaling factor $(F)$ into the optimization corrected for variations in CCD dark current, excitation light intensity, sample shape, and fluorophore concentration. The residuals $(C)$ represent 'unexplained' spectral information (noise).

Eppendorf, Hamburg, Germany) through the basal joint membrane of one of the large antennae into the hemolymph space. The injection was followed using a stereomicroscope (SZH-ILLK; Olympus GmbH, Hamburg, Germany). After 2-6 hours of recovery in nutrient-free medium, the animal was transferred into a perfusion chamber as described elsewhere [73]. The flow rate of the perfusion medium was maintained at $5.5 \mathrm{ml} \mathrm{min}^{-1}$ using a peristaltic pump (MCP Standard ISM 404; Ismatec SA, Glattbrugg, Swiss). The initial $\mathrm{pH}$ of the perfusion 
medium corresponded to the acclimation $\mathrm{pH}$ of the animals. During the experiment, the animal was exposed to a stepwise variation in ambient $\mathrm{pH}$ using the following sequence: initial (acclimation) $\mathrm{pH}$ (33 min), $\mathrm{pH} 4.0$ (35 $\mathrm{min}), \mathrm{pH} 3.0$ (18 $\mathrm{min})$, and acclimation $\mathrm{pH}$ (34 min). All perfusion media were buffered using $5 \mathrm{mM}$ HEPES ( $\mathrm{pH}$ 7.8), $5 \mathrm{mM}$ MES (pH 6.0), or $5 \mathrm{mM}$ citrate (pH 5.5, 4.0, 3.0). The medium $\mathrm{pH}$ was continuously controlled using a pH electrode ( $\mathrm{N}$ 6000). During the experiment, the fluorescence-spectrum acquisition alternated with the acquisition of video images of the animal under infrared transillumination. From these video sequences, the heart rate and appendage beating rate was determined by digital motion analysis as described elsewhere [73].

\section{Analysis of in vivo cSNARF-I spectra}

cSNARF-1 fluorescence spectra were obtained from the hemolymph space around the heart region. Since all tested animals were in a fasting state, the in vivo spectra did not contain any noticeable contributions from ingested autofluorescing algae which, if present, would have seriously affected the $\mathrm{pH}$ determination. The excellent quality of the in vivo CSNARF-1 spectra (Figure 6A) made it possible to determine the in vivo $\mathrm{pH}$ with high precision using multicomponent analysis (Additional file 4) [139]. Since the in vivo spectra could not be fitted by the calibration spectra (Figure 5B), probably due to a calibration-inherent distortion of the acid spectrum around 600-700 nm, new acid/base spectra of cSNARF-1 were measured in Daphnia magna hemolymph. The hemolymph samples were acidified by equilibration with $100 \%$ $\mathrm{CO}_{2}$ gas and basified by the addition of $\mathrm{NaOH}$ under $\mathrm{CO}_{2}$-free gas conditions $\left(100 \% \mathrm{~N}_{2}\right)$. As a modification to the calibration experiment, the micro-pH-electrode was not inserted into the hemolymph samples to avoid any optical interferences. The obtained acid/base spectra (Figure $6 \mathrm{~B}$ ) were finally scaled to the peak-to-peak ratio of the calibration spectra (Figure 5B). The multicomponent analysis determined the fractional contribution $(\alpha)$ of the acid form of CSNARF-1 to the in vivo spectra. The $\mathrm{pH}$ was finally calculated from $\alpha$ and the $\mathrm{p} K_{\mathrm{a}}^{\prime}$ value of CSNARF-1 (Figure 6D) according to

$$
\mathrm{pH}=\mathrm{p} K_{\mathrm{a}}^{\prime}+\log _{10} \frac{\alpha}{1-\alpha} .
$$

\section{Respiration measurements}

The oxygen consumption rate $\left(\dot{M}_{\mathrm{O}_{2}}\right)$ of a group of 3-4 animals (2.0-3.3 mm body length) carrying parthenogenetic embryos of developmental stage 1-2 [138] was measured at $20^{\circ} \mathrm{C}$ as described elsewhere [74]. The respiratory medium consisted of M4 medium containing 10 mM buffer (HEPES: pH 7.8, MES: pH 6.0, citrate: pH 5.5). Tetrazyclin and Streptomycin (12.5 $\mathrm{mg} \mathrm{l}^{-1}$ each) was
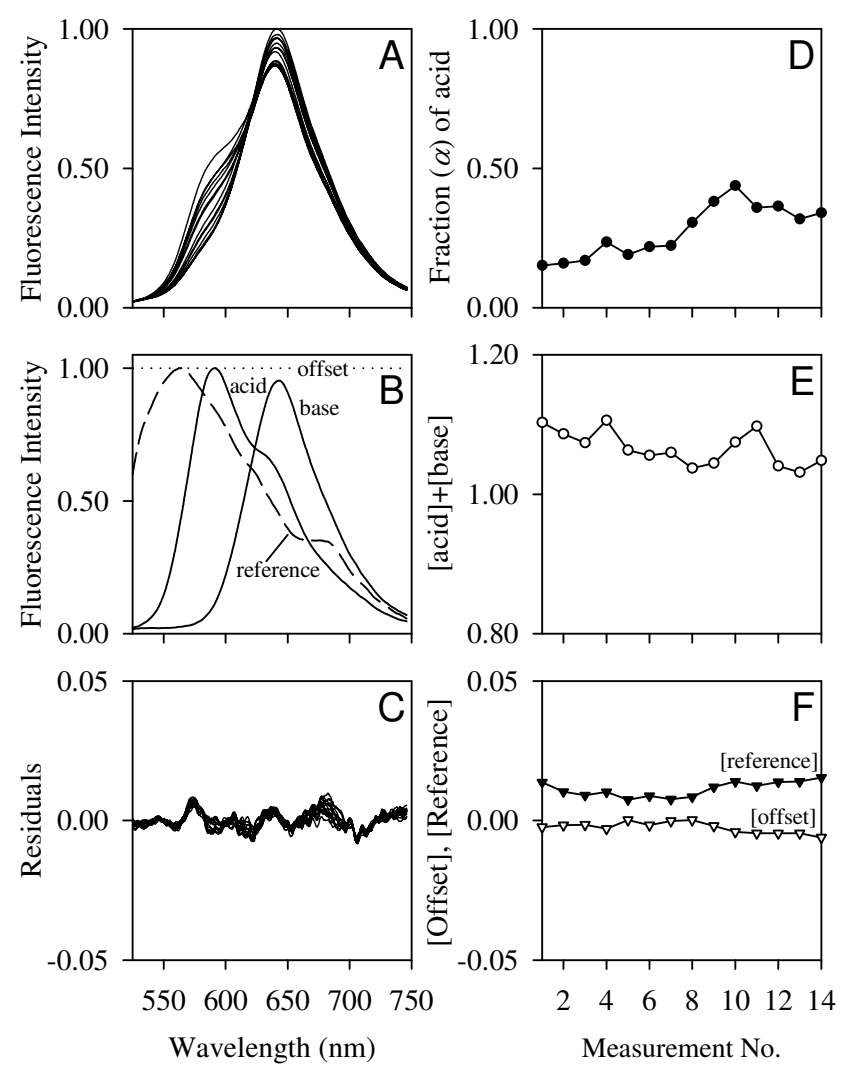

Figure 6

Analysis of in vivo cSNARF-I spectra. Example in vivo spectra (A) from a pH 7.8 acclimated Daphnia pulex exposed to ambient $\mathrm{pH}$ 7.8-3.0. The corresponding $\mathrm{pH}$ values were retrieved by a multicomponent analysis [139] (Additional file 4 ), which determines the composition of a mixture of components, given that the spectrum of each component is known. The component spectra (B) comprised the in vitro spectra of the acid/base forms of cSNARF-I (measured in Daphnia hemolymph), a reference (autofluorescence) spectrum from non-injected animals, and an offset (background) spectrum. The multicomponent analysis yielded the fraction of the acid form (D), the relative chromophore (acid plus base) concentration (E), as well as the contributions of the reference and offset signals (F). The residuals (C) represent spectral information that could not be explained by the component signals.

added to reduce bacterial respiration. The specific oxygen consumption rate was obtained by dividing the wholeanimal oxygen consumption rate by the cubic body length.

\section{Modelling of whole-animal $\mathrm{CO}_{2}$ transport}

A topological model was derived from a geometric concept on convective-diffusive oxygen transport in daphnids $[71,112]$. In this concept, the animal's complex body is reduced to a cylindrical trunk which is wrapped by a hol- 
low cylinder representing the carapace (Figure 3A). The carapace is a double-walled, hollow structure that is perfused with hemolymph. The hollow-cylindric space between the carapace and the trunk is occupied by the respiratory medium. As a simplification of the reference model (Figure 3A), the present model is composed of only five subdomains (Figure 3B). These are the inner hemolymph lacuna, a single tissue layer, the outer hemolymph lacuna, the respiratory medium, and the carapace hemolymph lacuna, as outlined in the conceptual overview of the compartment model (Figure 3C). Each subdomain has a total length $L$ and is divided into $N$ compartments of length $\mathrm{d} L$.

The processes operating within each compartment and in between adjacent/connected compartments include (i) the excretion of $\mathrm{CO}_{2}$ from tissue into hemolymph, (ii) the $\mathrm{CO}_{2}$ hydration and acid-base reactions in hemolymph and medium, (iii) the convective transport of reaction species, and (iv) the diffusive transport of $\mathrm{CO}_{2}$ across cuticular barriers. A mathematical formulation of the physico-chemical processes is given for a single compartment of the outer hemolymph lacuna. For compartments of other subdomains, equations can be derived in an analogous manner.

(i) The rate $\left(\mathrm{nmol} \mathrm{s}{ }^{-1}\right)$ at which $\mathrm{CO}_{2}$ is excreted from a tissue compartment of thickness $\mathrm{d} L$ into the outer hemolymph lacuna is $\phi F_{\text {ex }}$ with

$$
F_{\mathrm{Ex}}=\dot{M}_{\mathrm{CO}_{2}} \mathrm{~d} L / L,
$$

where $\dot{M}_{\mathrm{O}_{2}}$ is the whole-animal $\mathrm{CO}_{2}$ production rate. The factor $\phi$ is the fraction of excreted $\mathrm{CO}_{2}$ that is released into the outer hemolymph lacuna. The remaining fraction (1$\phi$ ) is received by the inner hemolymph lacuna.

(ii) The hydration and subsequent dissociation of $\mathrm{CO}_{2}$, its combination with $\mathrm{OH}^{-}$, and the dissociation of bicarbonate and the non-bicarbonate buffer HA are given by

$$
\begin{array}{ccc}
\mathrm{CO}_{2}+\mathrm{H}_{2} \mathrm{O} & \underset{\mu \cdot k_{1}}{\stackrel{\mu \cdot k_{1} / K_{1}^{\prime}}{\rightleftarrows}} \mathrm{H}^{+}+\mathrm{HCO}_{3}^{-} \\
\mathrm{HCO}_{3}^{-} & \stackrel{k_{2} / K_{2}^{\prime}}{\rightleftarrows} & \mathrm{H}^{+}+\mathrm{CO}_{3}^{2-} \\
\mathrm{CO}_{2}+\mathrm{OH}^{-} & \stackrel{k_{3}}{\rightleftarrows k_{-3}} & \mathrm{HCO}_{3}^{-} \\
\mathrm{HA} & \stackrel{k_{4} / K_{\mathrm{A}}^{\prime}}{\rightleftarrows} & \mathrm{H}^{+}+\mathrm{A}^{-}
\end{array}
$$

The lower and upper-case $k$ s represent kinetic and thermodynamic constants (Table 5), whereas $\mu$ is the factor by which the uncatalyzed interconversion between $\mathrm{CO}_{2}$ and
$\mathrm{HCO}_{3}^{-}$is accelerated in the presence of a carbonic anhydrase. The turnover rates $\left(\mathrm{mol} \mathrm{L}^{-1} \mathrm{~s}^{-1}\right)$ of the forward and backward reactions are defined as

$$
\begin{gathered}
R_{1}=\mu k_{1}\left[\mathrm{CO}_{2}\right] \\
R_{-1}=\mu k_{1} / K_{1}^{\prime}\left\{\mathrm{H}^{+}\right\}\left[\mathrm{HCO}_{3}^{-}\right] \\
R_{2}=k_{2} / K_{2}^{\prime}\left[\mathrm{HCO}_{3}^{-}\right] \\
R_{-2}=k_{2}\left\{\mathrm{H}^{+}\right\}\left[\mathrm{CO}_{3}^{2-}\right] \\
R_{3}=k_{3} \cdot K_{\mathrm{w}}^{\prime}\left[\mathrm{CO}_{2}\right] /\left\{\mathrm{H}^{+}\right\} \\
R_{-3}=k_{-3}\left[\mathrm{HCO}_{3}^{-}\right] \\
R_{4}=k_{4} / K_{\mathrm{A}}^{\prime}[\mathrm{HA}] \\
R_{-4}=k_{4}\left\{\mathrm{H}^{+}\right\}\left[\mathrm{A}^{-}\right]
\end{gathered}
$$

The hydrogen activity, $\left\{\mathrm{H}^{+}\right\}$, was calculated from hydrogen concentration as $\left\{\mathrm{H}^{+}\right\}=\gamma_{\mathrm{H}}\left[\mathrm{H}^{+}\right]$. The $\mathrm{H}^{+}$activity coefficient $\left(\gamma_{\mathrm{H}}=0.797\right)$ was determined for an ionic strength of 0.06 at $20^{\circ} \mathrm{C}$ using the Güntelberg approximation [140].

(iii) The net convective mass flow (nmol s${ }^{-1}$ ) of each reaction species $\left(\mathrm{X}=\mathrm{H}^{+}, \mathrm{CO}_{2}, \mathrm{HCO}_{3}^{-}, \mathrm{CO}_{3}^{2-}, \mathrm{HA}, \mathrm{A}^{-}\right)$from the upstream compartment into the compartment in consideration is

$$
F_{\mathrm{X}}=\rho \dot{Q}_{\mathrm{b}}\left([\mathrm{X}]_{\text {upstream }}-[\mathrm{X}]\right),
$$

where $[\mathrm{X}]$ and $[\mathrm{X}]_{\text {upstream }}$ represent the species concentrations in the compartment in focus and in the upstream compartment. The factor $\rho$ is the fraction of total hemolymph flow $\left(\dot{Q}_{b}\right)$ that is fed into the outer hemolymph lacuna.

(iv) The rate $\left(\mathrm{nmol} \mathrm{s}{ }^{-1}\right)$ of transcuticular $\mathrm{CO}_{2}$ diffusion, which depends on the difference in $\mathrm{CO}_{2}$ partial pressure between the outer HL lacuna $\left(P_{\mathrm{ho}}\right)$ and the medium $\left(P_{\mathrm{m}}\right)$, is defined as

$$
F_{\mathrm{Dt}}=K \frac{A_{\mathrm{tr}} \mathrm{d} L / L}{\Delta x_{\mathrm{tr}}}\left(P_{\mathrm{ho}}-P_{\mathrm{m}}\right) .
$$


Table 5: Parameter values of the $\mathrm{CO}_{2}$ transport model.

\begin{tabular}{|c|c|c|c|}
\hline Symbol & Value & Unit & Description \\
\hline$L$ & 2.38 & $\mathrm{~mm}$ & Length of exchange coordinate \\
\hline$A_{\mathrm{ca}}$ & 7.57 & $\mathrm{~mm}^{2}$ & Exchange surface area of the inner carapace cuticle \\
\hline$A_{\mathrm{tr}}$ & 5.34 & $\mathrm{~mm}^{2}$ & Exchange surface area of the trunk cuticle \\
\hline$\Delta x_{\mathrm{ca}}$ & 0.001 & $\mathrm{~mm}$ & Thickness of the inner carapace cuticle \\
\hline$\Delta x_{\mathrm{tr}}$ & 0.002 & $\mathrm{~mm}$ & Thickness of the trunk cuticle \\
\hline$Q_{\mathrm{b}}$ & 0.022 & $\mathrm{~mm}^{3} \mathrm{~s}^{-1}$ & Perfusion rate \\
\hline$V_{\mathrm{m}}$ & 0.7 & $\mathrm{~mm}^{3} \mathrm{~s}^{-1}$ & Medium flow rate \\
\hline$v_{\mathrm{b}}$ & 0.168 & $\mathrm{~mm} \mathrm{~s}^{-1}$ & Hemolymph flow velocity, backward direction \\
\hline$v_{\mathrm{f}}$ & 0.149 & $\mathrm{~mm} \mathrm{~s}^{-1}$ & Hemolymph flow velocity, forward direction \\
\hline$v_{\mathrm{m}}$ & 1.8 & $\mathrm{~mm} \mathrm{~s}^{-1}$ & Medium flow velocity \\
\hline $\mathrm{M}_{\mathrm{CO}}$ & 0.0071 & $\mathrm{nmol} \mathrm{s} \mathrm{s}^{-1}$ & Whole-animal $\mathrm{CO}_{2}$ production rate \\
\hline$\alpha_{\mathrm{CO}_{2}}$ & 0.3682 & $\mathrm{nmol} \mathrm{mm} \mathrm{m}^{-3} \mathrm{kPa}^{-1}$ & Physical solubility of $\mathrm{CO}_{2}$ in medium and hemolymph \\
\hline$K$ & $2.10 \times 10^{-6}$ & $\mathrm{nmol} \mathrm{s} \mathrm{sm}^{-1} \mathrm{kPa}^{-1}$ & Krogh's diffusion constant for $\mathrm{CO}_{2}$ in chitin \\
\hline$K_{1}^{\prime}$ & $10^{-6.325}$ & M & Dissociation equilibrium constant of $\mathrm{CO}_{2}$ \\
\hline$K_{2}^{\prime}$ & $10^{-10.47}$ & M & Dissociation equilibrium constant of $\mathrm{HCO}_{3}^{-}$ \\
\hline$K_{\mathrm{A}}^{\prime}$ & $10^{-8.18}$ & M & Dissociation equilibrium constant of the NB buffer \\
\hline$K_{\mathrm{w}}^{\prime}$ & $10^{-14}$ & M & Dissociation equilibrium constant of water \\
\hline$k_{1}$ & 0.022 & $s^{-1}$ & Rate constant for $\mathrm{CO}_{2}$ hydration \\
\hline$k_{2}$ & $10^{10}$ & $M^{-1} s^{-1}$ & Rate constant for the protonation of $\mathrm{CO}_{3}^{2-}$ \\
\hline$k_{3}$ & 5500 & $M^{-1} s^{-1}$ & Rate constant for the reaction of $\mathrm{CO}_{2}$ with $\mathrm{OH}^{-}$ \\
\hline$k_{-3}$ & $1.1 \times 10^{-4}$ & $s^{-1}$ & Rate constant for: $\mathrm{HCO}_{3}^{-} \rightarrow \mathrm{CO}_{2}+\mathrm{OH}^{-}$ \\
\hline$k_{4}$ & $10^{10}$ & $M^{-1} s^{-1}$ & Rate constant for the protonation of the NB buffer \\
\hline$\mu$ & I & & Acceleration factor for $\mathrm{CO}_{2} / \mathrm{HCO}_{3}^{-}$interconversion \\
\hline$\rho$ & 0.5 & & Fraction of $\dot{Q}_{\mathrm{b}}$ entering the outer $\mathrm{HL}$ lacuna \\
\hline$\phi$ & 0.2 & & Fraction of $\mathrm{CO}_{2}$ excreted into the outer $\mathrm{HL}$ lacuna \\
\hline$\gamma_{H}$ & 0.797 & & Hydrogen activity coefficient \\
\hline
\end{tabular}


Table 5: Parameter values of the $\mathrm{CO}_{2}$ transport model. (Continued)

\begin{tabular}{clll}
\hline $\mathrm{C}_{\mathrm{A}}$ & 3.6 & $\mathrm{nmol} \mathrm{mm}$ & Concentration of the NB buffer in the hemolymph \\
\hline$P_{\text {in }}$ & 0.035 & $\mathrm{kPa}$ & Inspiratory $\mathrm{CO}_{2}$ partial pressure \\
\hline $\mathrm{pH}_{\text {in }}$ & 8.0 & $\mathrm{pH}$ of the inspired medium \\
\hline$\left[\mathrm{HCO}_{3}^{-}\right]_{\text {in }}$ & 0.6 & $\mathrm{nmol} \mathrm{mm}$ & Bicarbonate concentration of the inspired medium
\end{tabular}

These parameter values were used to generate the profiles in acid-base variables shown in Figure 3D. The values for $K$ and $\mu$ refer to the uncatalyzed case in the absence of a carbonic anhydrase in the hemolymph. The catalyzed case was derived from this parameter setting by two adjustments $\left(\mu=10000, K=1.30 \times 10^{-6} \mathrm{nmol} \mathrm{s}^{-1} \mathrm{~mm}^{-1} \mathrm{kPa}^{-1}\right)$. NB = non-bicarbonate.

$K$ is Krogh's diffusion coefficient, whereas $\Delta x_{\mathrm{tr}}$ and $A_{\mathrm{tr}} \mathrm{d} L / L$ represents the thickness and surface area of the cuticular barrier at the hemolymph/medium interface.

The temporal changes in the concentration of all reaction partners for the specified compartment of volume $V$ (= $\left.\rho \dot{Q}_{\mathrm{b}} \mathrm{d} L / v_{\mathrm{f}}\right)$ are expressed as

$$
\mathrm{d}\left[\mathrm{H}^{+}\right] / \mathrm{d} t=R_{1}-R_{-1}+R_{2}-R_{-2}+R_{3}-R_{-3}+R_{4}-R_{4}+F_{\mathrm{H}^{+}} / V
$$

$\mathrm{d}\left[\mathrm{CO}_{2}\right] / \mathrm{d} t=-R_{1}+R_{-1}-R_{3}+R_{-3}+\left(F_{\mathrm{CO}_{2}}+\varphi F_{\mathrm{Ex}}-F_{\mathrm{Dt}}\right) / V$

$$
\mathrm{d}\left[\mathrm{HCO}_{3}^{-}\right] / \mathrm{d} t=R_{1}-R_{-1}-R_{2}+R_{-2}+R_{3}-R_{-3}+F_{\mathrm{HCO}_{3}^{-}} / V
$$

$$
\begin{gathered}
\mathrm{d}\left[\mathrm{CO}_{3}^{2-}\right] / \mathrm{d} t=R_{2}-R_{-2}+F_{\mathrm{CO}_{3}^{2-}} / V \\
\mathrm{~d}[\mathrm{HA}] / \mathrm{d} t=-R_{4}+R_{-4}+F_{\mathrm{HA}} / V \\
\mathrm{~d}\left[\mathrm{~A}^{-}\right] / \mathrm{d} t=R_{4}-R_{-4}+F_{\mathrm{A}^{-}} / V
\end{gathered}
$$

Parameter values (Table 5) related to geometry, convection and respiration were obtained from a reference model (R. Moenickes, O. Richter and R. Pirow, in preparation). All perfusion-related parameter values were set to $50 \%$ of the reference values to take the low heart rates of animals from the present study into account. The rate constants for the reaction of $\mathrm{CO}_{2}$ with $\mathrm{H}_{2} \mathrm{O}$ and $\mathrm{OH}^{-}$at $20^{\circ} \mathrm{C}$ were obtained from [141]. The acceleration factor $(\mu)$ was set to 10000 [126], which is sufficiently large to attain an equilibrium in the $\mathrm{CO}_{2}+\mathrm{H}_{2} \mathrm{O} \leftrightarrow \mathrm{H}^{+}+\mathrm{HCO}_{3}^{-}$reaction. The protonation rate constant for the carbonate and the nonbicarbonate buffer was assumed to be of the magnitude of $10^{10} \mathrm{M}^{-1} \mathrm{~s}^{-1}$ [111]. The dissociation equilibrium constants of all reaction species as well as the physical solubility of $\mathrm{CO}_{2}$ were taken from the present study. An operational value for Krogh's diffusion constant $(K)$ for $\mathrm{CO}_{2}$ in chitin was chosen as such that the $\mathrm{pH}$ at the entrance of the inner hemolymph lacuna (Figure 3C) assumed a value of $\mathrm{pH}$ 8.334 under steady-state conditions. The cuticular barrier was assumed to be impermeable for all reaction species except $\mathrm{CO}_{2}$, and the medium compartment lacked a nonbicarbonate buffer. The initial conditions for the hemolymph were $\mathrm{pH} 8.334$ and $0.556 \mathrm{kPa} P_{\mathrm{CO} 2}$. The initial conditions of the medium compartment were set to the properties of the inspired medium ( $\mathrm{pH} 8.06$ and 0.035 $\mathrm{kPa} P_{\mathrm{CO} 2}$ ). A number of $N=50$ compartments was chosen per subdomain. Starting with the initial conditions, the model status was allowed to evolve until quasi steadystate conditions (relative concentration changes $<10^{-6}$ ) were reached.

\section{Statistics and Numerics}

If not stated otherwise, data are expressed as means \pm standard error, with $N$ indicating the number of independent measurements. Differences in a physiological variable among the acclimation groups were checked using a one-way analysis on variance (ANOVA) or the Kruskal-Wallis test, depending on whether the data passed the normality test and the equal variance test. Statistical differences were considered as significant at $P<0.05$. Multiple pairwise comparisons against the control ( $\mathrm{pH} 7.8$ ) group were performed using the Holm-Sidak test or Dunn's method, using an experimentwise significance level of 0.05. All statistical analyses were performed using SigmaStat (version 3.1; SPSS Inc.).

Numerical problems were solved in Matlab 7.0 (MathWorks, Inc.). The 'Isqnonlin' function (optimization toolbox) was used to fit the model in equation 1 to the $P_{\mathrm{CO}_{2}}{ }^{-}$ $\mathrm{pH}$ data. The uncertainty in the calculation of $P_{\mathrm{CO} 2}$ given the $\mathrm{pH}$ and the calibration buffer curve, was determined by a nonlinear algorithm $[142,143]$. The 'rlowess' function (curve-fitting toolbox) was applied for the smoothing 
of spectra. In-built functions for matrix operations (including that for the calculation of the Moore-Penrose pseudoinverse) were used to implement the reiterative least-squares spectral resolution [137] and the multicomponent analysis [139] (Additional file 4), whereas the 'fminsearch' function (optimization toolbox) provided the Nelder-Mead simplex algorithm [144]. The nonlinear system of ordinary differential equations (ODEs) was numerically solved using the 'ode 15 s' solver for stiff problems.

\section{Annotations, sequence alignments and phylogenetic analysis}

The D. pulex genome database was screened for carbonic anhydrase-like sequences by a keyword search in the automatically-created annotations and by a 'blastp alignment search' of the Dappu v1.1 gene builds (July, 2007) [117]. All gene models containing carbonic anhydrase-like sequences were manually curated and annotated (Table $4)$. The derived amino-acid sequences were classified using the conserved domain database (CDD) and search engine v2.13 $[145,146]$. Homolog sequences from other organisms were retrieved using the blastp algorithm [147]. All sequences were checked for the presence of $\mathrm{N}$ terminal signal peptides using the SignalP V3.0 server [148-150]. Potential GPI-anchor sites were identified by GPI-SOM [151,152], the big-PI Predictor [153,154] and FragAnchor $[155,156]$. Multiple-sequence alignments were performed using the T-Coffee algorithm [157-159] and displayed with ESPript [160,161]. Phylogenetic trees were constructed using the neighbor-joining algorithm [162] and a bootstrap analysis with 1000 replicates. Trees were visualized using iTOL $[163,164]$.

\section{Abbreviations}

$A_{\mathrm{ca}}$ : exchange surface area of the inner carapace cuticle; $A_{\mathrm{tr}}$ : exchange surface area of the trunk cuticle; $C_{\mathrm{A}}$ : concentration of the non-bicarbonate buffer; $f_{\mathrm{A}}$ : appendage beating rate; $f_{\mathrm{H}}$ : heart rate; $F_{\mathrm{Dc}}$ : rate of $\mathrm{CO}_{2}$ diffusion across the inner carapace cuticle; $F_{\mathrm{Dt}}$ : rate of $\mathrm{CO}_{2}$ diffusion across the trunk cuticle; $F_{\mathrm{Ex}}$ : $\mathrm{CO}_{2}$ excretion rate; $F_{\mathrm{X}}$ : net convective mass flow $\left(\mathrm{X}=\mathrm{H}^{+}, \mathrm{CO}_{2}, \mathrm{HCO}_{3}^{-}, \mathrm{CO}_{3}^{2-}, \mathrm{HA}, \mathrm{A}^{-}\right) ; \mathrm{K}$ : Krogh's diffusion constant for $\mathrm{CO}_{2}$ in chitin; $K_{1}^{\prime}$ : first dissociation equilibrium constant of the carbonate system; $K_{2}^{\prime}$ : second dissociation equilibrium constants of the carbonate system; $K_{\mathrm{A}}^{\prime}$ : dissociation equilibrium constant of the non-bicarbonate buffer; $K_{\mathrm{a}}^{\prime}$ : dissociation equilibrium constant of cSNARF-1; $K_{\text {w }}^{\prime}$ : dissociation equilibrium constant of water; $k_{1}$, rate constant for $\mathrm{CO}_{2}$ hydration; $k_{2}$ : rate constant for the protonation of $\mathrm{CO}_{3}^{2-} ; k_{3}$, rate constant for the reaction of $\mathrm{CO}_{2}$ with $\mathrm{OH}_{-} ; k_{-3}$ : rate constant for the dissociation of $\mathrm{HCO}_{3}^{-}$into $\mathrm{CO}_{2}$ and $\mathrm{OH}^{-} ; k_{4}$ : rate constant for the protonation of the non-bicarbonate buffer; $L$ : length of the exchange coordinate; $\mathrm{d} L$ : compartment thickness; $\dot{M}_{\mathrm{CO}_{2}}$ : whole-animal $\mathrm{CO}_{2}$ production rate; $\dot{M}_{\mathrm{O}_{2}}$ : volume-specific $\mathrm{O}_{2}$ consumption rate; $P_{\mathrm{CO} 2}: \mathrm{CO}_{2}$ partial pressure; $P_{\text {in }}$ : inspiratory $\mathrm{CO}_{2}$ partial pressure; $P_{\mathrm{hi}}$ : $\mathrm{CO}_{2}$ partial pressure in the inner hemolymph lacuna; $P_{\mathrm{ho}}$ : $\mathrm{CO}_{2}$ partial pressure in the outer hemolymph lacuna; $P_{\mathrm{m}}$ : $\mathrm{CO}_{2}$ partial pressure in the medium; $\mathrm{pH}_{\mathrm{in}}$ : $\mathrm{pH}$ values of the inspired medium; $\dot{Q}_{\mathrm{b}}$ : perfusion rate; $R_{\mathrm{Y}}$ : turnover rates $(\mathrm{Y}=1,-1,2,-2,3,-3,4,-4)$; SID: strong ion difference; $V$ : compartment volume; $\dot{V}_{\mathrm{m}}$ : medium flow rate; $v_{\mathrm{b}}$ : hemolymph flow velocity in backward direction; $v_{\mathrm{f}}$ : hemolymph flow velocity in forward direction; $v_{\mathrm{m}}$ : medium flow velocity; $\alpha$ : fraction of acid; $\alpha_{\mathrm{CO} 2}$ : physical solubility of $\mathrm{CO}_{2}$ in water and hemolymph; $\beta_{\mathrm{A}}$ : non-bicarbonate buffer value; $\beta_{\mathrm{B}}$ : bicarbonate buffer value; $\beta_{\mathrm{C}}$ : carbonate buffer value; $\beta_{\Gamma}$ : total buffer value; $\Delta \mathrm{H}^{+}$: metabolic acid load; $\Delta x_{\text {ca }}$ : thickness of the inner carapace cuticle; $\Delta x_{\mathrm{tr}}$ : thickness of the trunk cuticle; $\gamma_{\mathrm{H}}: \mathrm{H}^{+}$activity coefficient; $\rho$ : fraction of total hemolymph flow entering the outer hemolymph lacuna; $\phi$ : fraction of $\mathrm{CO}_{2}$ excreted into the outer hemolymph lacuna; $\mu$ : acceleration factor for the interconversion between $\mathrm{CO}_{2}$ and $\mathrm{HCO}_{3}^{-}$.

\section{Authors' contributions}

AKW and RP conceived the study, carried out the methodical developments, and wrote the manuscript. AKW carried out the experiments. $\mathrm{RP}$ implemented the numerical tools, developed and implemented the $\mathrm{CO}_{2}$ transport model, and annotated the carbonic anhydrase genes. Both authors read and approved the final manuscript. 


\section{Additional material}

\section{Additional file 1}

Multiple sequence alignment of $\alpha$-carbonic anhydrases. The $\alpha$-CA sequences are divided into four groups according to similarity. Residues strictly conserved have a red background, residues well conserved within a group according to a Risler matrix [122] are indicated by red letters. Residues conserved between groups are boxed. Secondary structure elements of three human $\alpha$-CAs are shown in blue on the top: helices with squiggles, beta strands with arrows, alpha and beta turns with TTT and TT letters. The numbering refers to HsCA2. Amino acid residues involved in zincbinding and in the hydrogen-bonding network are indicated by red triangles. Yellow and orange backgrounds indicate mitochondrial targeting peptide or predicted signal peptides for secretory export. Pink and green backgrounds signify a transmembrane domain or potential glycosylphosphatidylinositol (GPI) anchor sites. Daphnia pulex sequences are indicated by red labels. Additionally included were related sequences from the blue crab Callinectes sapidus (Cs), Drosophila melanogaster (Dm), Anopheles gambiae ( $\mathrm{Ag})$, Caenorhabditis elegans $(\mathrm{Ce})$, the sea urchin Strongylocentrotus purpuratus (Sp), and Homo sapiens (Hs). Sequences were aligned using the T-Coffee algorithm [158] and displayed with ESPript $[120,161]$. Sequence references, protein data bank (PDB) codes and NCBI accession numbers: Callinectes [124], Drosophila [119], Anopheles [125], HsCA2 (1CA2), HsCA4 (1ZNC), HsCA5A (NP_001730), HsCA6 (P23280), HsCA10 (AAH29865), HsCA12 (1JCZ), CeCAH2 (Q18932), SpCA8 (XP_795365), SpCAc (XP_782997), SpCA-RP (XP_784796), SpCA-GPI (XP_796525). Click here for file

[http://www.biomedcentral.com/content/supplementary/14726793-9-9-S1.pdf]

\section{Additional file 2}

Multiple sequence alignment of $\beta$-carbonic anhydrases. Numbering and the secondary structure elements on the top refer to the $\beta$-CA from Pisum sativum (PsCAb) [121]. The other sequences are from Daphnia pulex (CAB), Drosophila melanogaster (DmCG11967), Anopheles gambiae $(A g C A b)$, Caenorhabditis elegans (CeCAb1), sea urchin Strongylocentrotus purpuratus ( $S p C A b)$, and the sea anemone Nematostella vectensis $(\mathrm{N} v \mathrm{CAb})$. A column is framed in blue if more than $70 \%$ of its residues are similar according to physico-chemical properties. Similar residues are indicated by red letters; strictly conserved residues have a red background. Secondary structure elements are presented as follows: helices with squiggles, beta strands with arrows, alpha and beta turns with TTT and TT letters. Amino acid residues involved in zinc and substrate binding are indicated by red and blue triangles. Sequences were aligned using the T-Coffee algorithm [158] and displayed with ESPript $[120,161]$. Protein data bank (PDB) code and NCBI accession numbers: PsCAb (2EKJ), DmCG11967 (NP_649849), AgCAb (XP_563117), CeCAb1 (NP_741809), SpCAb (XP_786120), NvCAb (XP_001632619).

Click here for file

[http://www.biomedcentral.com/content/supplementary/14726793-9-9-S2.pdf]

\section{Additional file 3}

Determination of operational $p \mathrm{~K}^{\prime}$ values and correction for incomplete equilibration. This supplement describes experimental determination of $p \mathrm{~K}_{1}^{\prime}$ and $p \mathrm{~K}_{2}$ from standard bicarbonate solutions $(4,8$, and $16 \mathrm{mM}$ $\mathrm{NaHCO}_{3}$ plus $50 \mathrm{mM} \mathrm{NaCl}$ ). It also outlines the analytical procedure for the correction of incomplete equilibration of bicarbonate and hemolymph samples at low $\mathrm{CO}_{2}$ partial pressures.

Click here for file

[http://www.biomedcentral.com/content/supplementary/14726793-9-9-S3.pdf]

\section{Additional file 4}

Reiterative least-squares spectral resolution \& multicomponent anal$y s i s$. This supplement describes the reiterative least-squares spectral resolution, which was employed for the determination of the $p \mathrm{~K}^{\prime}$ value and the acid/base spectra of CSNARF-1. It also outlines the multicomponent analysis, which was used to retrieve the in vivo $p H$ from in vivo spectra of cSNARF.

Click here for file

[http://www.biomedcentral.com/content/supplementary/14726793-9-9-S4.pdf]

\section{Acknowledgements}

We thank Dr. Stefan Hetz (Humboldt-University of Berlin) for his generous and lasting loan. The expert technical contributions of Ina Buchen and Olaf Pinkhaus (University of Münster) are also gratefully acknowledged.

The sequencing and portions of the analyses were performed at the DOE Joint Genome Institute under the auspices of the U.S. Department of Energy's Office of Science, Biological and Environmental Research Program, and by the University of California, Lawrence Livermore National Laboratory under Contract No. W-7405-Eng-48, Lawrence Berkeley National Laboratory under Contract No. DE-AC02-05CHI I23I, Los Alamos National Laboratory under Contract No. W-7405-ENG-36 and in collaboration with the Daphnia Genomics Consortium (DGC) http://daph nia.cgb.indiana.edu. Additional analyses were performed by wFleaBase, developed at the Genome Informatics Lab of Indiana University with support to Don Gilbert from the National Science Foundation and the National Institutes of Health. Coordination infrastructure for the DGC is provided by The Center for Genomics and Bioinformatics at Indiana University, which is supported in part by the METACyt Initiative of Indiana University, funded in part through a major grant from the Lilly Endowment, Inc. Our work benefits from, and contributes to the Daphnia Genomics Consortium.

\section{References}

I. Laudon $\mathrm{H}$, Westling $\mathrm{O}$, Bishop $\mathrm{K}$ : Cause of $\mathrm{pH}$ decline in stream water during spring melt runoff in northern Sweden. Can J Fish Aquat Sci 2000, 57(9): I888-1900.

2. Lepori F, Ormerod SJ: Effects of spring acid episodes on macroinvertebrates revealed by population data and in situ toxicity tests. Freshwat Biol 2005, 50(9): I568-I577.

3. Eppinger RG, Briggs PH, Dusel-Bacon C, Giles SA, Gough LP, Hammarstrom JM, Hubbard BE: Environmental geochemistry at Red Mountain, an unmined volcanogenic massive sulphide deposit in the Bonnifield district, Alaska Range, east-central Alaska. Geochem: Explor Environ Anal 2007, 7:207-223.

4. Satake K, Oyagi A, Iwao Y: Natural acidification of lakes and rivers in Japan: The ecosystem of Lake Usoriko (pH 3.4-3.8). Water Air Soil Pollut 1995, 85(2):5 I I-5 I6. 
5. Ezoe Y, Lin CH, Noto M, Watanabe Y, Yoshimura K: Evolution of water chemistry in natural acidic environments in Yangmingshan, Taiwan. J Environ Monit 2002, 4(4):533-540.

6. Hao JM, Tian HZ, Lu YQ: Emission inventories of $\mathbf{N O}_{\mathbf{x}}$ from commercial energy consumption in China, I995-1998. Environ Sci Technol 2002, 36(4):552-560.

7. Moiseenko TI: Effects of acidification on aquatic ecosystems. Russ J Ecol 2005, 36(2):93-102.

8. Kurvits T, Marta $\mathrm{T}$ : Agricultural $\mathbf{N H}_{3}$ and $\mathbf{N O}$ emissions in Canada. Environ Pollut 1998, 102:187-194.

9. Liu WX, Luan ZK, Tang HX: Use of the sediment quality triad to assess metal contamination in freshwater superficial sediments from the Le An River, China. Water Air Soil Pollut 1999 I I 3( I-4):227-239.

10. Cappuyns V, Swennen $R$, Devivier A: Dredged river sediments: Potential chemical time bombs? A case study. Water Air Soil Pollut 2006, I 7 I(I-4):49-66.

II. Geller W, Klapper H, Salomons W: Acidic mining lakes: Acid mine drainage, limnology and reclamation. Berlin: Springer Verlag; 1998.

12. Deneke R: Review of rotifers and crustaceans in highly acidic environments of $\mathbf{p H}$ values $\leq 3$. Hydrobiologia 2000, 433(I3): $167-172$.

13. Leivestad H, Hendrey G, Muniz IP, Snekvik E: Effects of acid precipitation on freshwater organisms. Impact of acid precipitation on forest and freshwater ecosystems in Norway: Summary report on the research results from the phase I (1972-1975) of the SNSF-project. Oslo: SNSF Project FR6/76 1976:86-III.

14. Brett MT: Zooplankton communities and acidification processes (a review). Water Air Soil Pollut 1989, 44(3-4):387-4I4.

15. Brönmark C, Hansson L-A: The biology of lakes and ponds. Oxford: Oxford University Press; 1998.

16. Holt CA, Yan ND, Somers KM: pH 6 as the threshold to use in critical load modeling for zooplankton community change with acidification in lakes of south-central Ontario: accounting for morphometry and geography. Can J Fish Aquat Sci 2003 , 60(2): $|5|-\mid 58$.

17. Kurbatova SA: [Response of microcosm zooplankton to acidification]. Izv Akad Nauk Ser Biol 2005:100-108.

18. Locke A: Zooplankton responses to acidification: A review of laboratory bioassays. Water Air Soil Pollut 1991, 60( I-2): | 35- |48.

19. Havens KE, Yan ND, Keller W: Lake acidification: Effects on crustacean zooplankton populations. Environ Sci Technol 1993. 27(8): I62I-I624.

20. Havas M, Likens GE: Toxicity of aluminum and hydrogen ions to Daphnia catawba, Holopedium gibberum, Chaoborus punctipennis, and Chironomus anthrocinus from Mirror Lake, New Hampshire. Can I Zool 1985, 63(5): III4-III9.

21. Havens KE: Aluminum binding to ion exchange sites in acidsensitive versus acid-tolerant cladocerans. Environ Pollut 1990 64(2): $|33-| 4 \mid$.

22. Lawrence SG, Holoka MH: Effects of low concentrations of cadmium on the crustacean zooplankton community of an artificially acidified lake. Can J Fish Aquat Sci 1987, 44:I63-I72.

23. Locke A, Sprules WG: Effects of acidic $\mathbf{p H}$ and phytoplankton on survival and condition of Bosmina longirostris and Daphnia pulex. Hydrobiologia 2000, 437(1-3):187-196.

24. Wood CM: The physiological problems of fish in acid waters. In Acid toxicity and aquatic animals Edited by: Morris R, Taylor EW, Brown DJA, Brown JA. Cambridge: Cambridge University Press; 1989:125-152.

25. McMahon BR, Stuart SA: The physiological problems of crayfish in acid waters. In Acid toxicity and aquatic animals Edited by: Morris R, Taylor EW, Brown DJA, Brown JA. Cambridge: Cambridge University Press; 1989:17|-200.

26. Mantel LH, Farmer LL: Osmotic and ionic regulation. In The biology of crustacea: Internal anatomy and physiological regulation Edited by: Mantel LH. New York: Academic Press; 1983:53-16I.

27. Krogh A: Osmotic regulation in aquatic animals. Cambridge: Cambridge University Press; 1939.

28. Potts WTW, Parry G: Osmotic and ionic regulation in animals. Oxford: Pergamon Press; 1964.

29. Rasmussen AD, Andersen O: Apparent water permeability as a physiological parameter in crustaceans. J Exp Biol 1996 I 99( I 2):2555-2564
30. Nilssen IP, Østdahl T, Potts WTW: Species replacements in acidified lakes: Physiology, predation or competition. Rep Inst Freshw Res Drottningholm 1984, 6 I: I48-I 53.

31. Vangenechten JHD, Witters H, Vanderborght OLJ: Laboratory studies on invertebrate survival and physiology in acid waters. In Acid toxicity and aquatic animals Edited by: Morris R, Taylor EW, Brown DJA, Brown JA. Cambridge: Cambridge University Press; 1989:153-169.

32. Havas $\mathrm{M}$, Advokaat $\mathrm{E}$ : Can sodium regulation be used to predict the relative acid-sensitivity of various life-stages and different species of aquatic fauna? Water Air Soil Pollut 1995, 85(2):865-870.

33. Potts WTW, Fryer G: The effects of $\mathbf{p H}$ and salt content on sodium balance in Daphnia magna and Acantholeberis curvirostris (Crustacea: Cladocera). I Comp Physiol 1979 I 29(4):289-294.

34. Havas M, Hutchinson TC, Likens GE: Effect of low pH on sodium regulation in two species of Daphnia. Can J Zool 1984, 62(10): $1965-1970$

35. Glover CN, Wood CA: Physiological characterisation of a $\mathbf{p H}$ and calcium-dependent sodium uptake mechanism in the freshwater crustacean, Daphnia magna. J Exp Biol 2005, 208(5):95।-959.

36. Pirow R, Wollinger F, Paul RJ: The sites of respiratory gas exchange in the planktonic crustacean Daphnia magna: An in vivo study employing blood haemoglobin as an internal oxygen probe. J Exp Biol I999, 202(22):3089-3099.

37. Péqueux A: Osmotic Regulation in Crustaceans. I Crustacean Biol 1995, I 5(I): I-60.

38. Zetino AM, Kirschner LB, Harvey M: On the mechanism of sodium-proton exchange in crayfish. Comp Biochem Physiol A Mol Integr Physiol 200 I, I 28(4):863-872.

39. Evans DH, Piermarini PM, Choe KP: The multifunctional fish gill: Dominant site of gas exchange, osmoregulation, acid-base regulation, and excretion of nitrogenous waste. Physiol Rev 2005, 85(I):97-I77.

40. Kirschner LB: The mechanism of sodium chloride uptake in hyperregulating aquatic animals. J Exp Biol 2004, 207(9): |439-| 452.

4I. Whiteley NM: Acid-base regulation in crustaceans: the role of bicarbonate ions. In Regulation of acid-base status in animals and plants Edited by: Egginton S, Taylor EW, Raven JA. Cambridge: Cambridge University Press; 1999.

42. Poynton HC, Varshavsky JR, Chang B, Cavigiolio G, Chan S, Holman PS, Loguinov AV, Bauer DJ, Komachi K, Theil EC, et al: Daphnia magna ecotoxicogenomics provides mechanistic insights into metal toxicity. Environ Sci Technol 2007, 4 I (3): I 044-1050.

43. Shaw JR, Colbourne JK, Davey JC, Glaholt SP, Hampton TH, Chen CY, Folt CL, Hamilton JW: Gene response profiles for Daphnia pulex exposed to the environmental stressor cadmium reveals novel crustacean metallothioneins. BMC Genomics 2007, 8:477.

44. Soetaert A, Vandenbrouck T, Ven K van der, Maras M, van Remorte $\mathrm{P}$, Blust R, de Coen WM: Molecular responses during cadmiuminduced stress in Daphnia magna: Integration of differential gene expression with higher-level effects. Aquat Toxicol 2007 83(3):212-222

45. Connon R, Hooper HL, Sibly RM, Lim FL, Heckmann LH, Moore DJ, Watanabe H, Soetaert A, Cook K, Maund SJ, et al.: Linking molecular and population stress responses in Daphnia magna exposed to cadmium. Environ Sci Technol 2008, 42(6):2 I 8 |-2 I 88

46. Heckmann LH, Sibly RM, Connon R, Hooper HL, Hutchinson TH, Maund SJ, Hill CJ, Bouetard A, Callaghan A: Systems biology meets stress ecology: linking molecular and organismal stress responses in Daphnia magna. Genome Biol 2008, 9(2):R40.

47. Eads BD, Andrews J, Colbourne JK: Ecological genomics in Daphnia: stress responses and environmental sex determination. Heredity 2008, I00(2): $184-190$

48. Pane EF, McGeer JC, Wood CM: Effects of chronic waterborne nickel exposure on two successive generations of Daphnia magna. Environ Toxicol Chem 2004, 23(4): I05I-I056.

49. Pane EF, Smith C, McGeer JC, Wood CM: Mechanisms of acute and chronic waterborne nickel toxicity in the freshwater cladoceran, Daphnia magna. Environ Sci Technol 2003, 37(19):4382-4389. 
50. Cameron JN: Effects of hypercapnia on blood acid-base status, $\mathrm{NaCl}$ fluxes, and trans-gill potential in freshwater blue crabs, Callinectes sapidus. Journal of Comparative Physiology 1978, | 23(2):|37-|4|.

5I. Cameron JN: Acid-base responses to changes in $\mathbf{C O}_{2}$ in two pacific crabs: The coconut crab, Birgus latro, and a mangrove crab, Cardisoma carnifex. Journal of Experimental Zoology 198I, 218(I):65-73.

52. Chen JC, Chen JS: Acid-base balance, ammonia and lactate levels in the haemolymph of Penaeus japonicus during aerial exposure. Comp Biochem Physiol A Mol Integr Physiol 1998, I2I(3):257-262

53. deFur PL, Wilkes PRH, McMahon BR: Non-equilibrium acid-base status in $C$. productus: Role of exoskeletal carbonate buffers. Respir Physiol I 980, 42(3):247-26I.

54. Greenaway $\mathrm{P}$, Bonaventura J, Taylor $\mathrm{HH}$ : Aquatic gas exchange in the australian freshwater/land crabs of the genus Holthuisana. J Exp Biol 1983, I03(Mar):225-236

55. Innes AJ, Forster ME, Jones MB, Marsden ID, Taylor HH: Bimodal respiration, water balance and acid-base regulation in a highshore crab, Cyclograpsus lavauxi H. Milne Edwards. Journal of Experimental Marine Biology and Ecology 1986, $100(1-3)$ : I27-I 45

56. McMahon B, Sinclair F, Hassall CD, Defur PL, Wilkes PRH: Ventilation and control of acid-base status during temperature acclimation in the crab, Cancer magister. Journal of Comparative Physiology 1978, I 28(2): 109-1 I6.

57. McMahon BR, Butler PJ, Taylor EW: Acid base changes during recovery from disturbance and during long term hypoxic exposure in the lobster Homarus vulgaris. Journal of Experimental Zoology 1978, 205(3):361-370.

58. Morris S, Edwards T: Circulatory, acid-base and respiratory responses of the purple shore crab Leptograpsus variegatus to immersion. Journal of Experimental Marine Biology and Ecology 1996 | 96(I-2):|89-2||

59. Morris S, Taylor AC, Bridges CR, Grieshaber MK: Respiratory properties of the hemolymph of the intertidal prawn Palaemon elegans (Rathke). J Exp Zool 1985, 233(2): 175-186.

60. Sartoris FJ: Ökophysiologische Untersuchungen zur Säuresensitivität der Bachflohkrebse Gammarus pulex (L.) und Gammarus fossarum (Koch). [PhD thesis, University of Düsseldorf] Aachen: Verlag Shaker; 1992.

61. Sinha NP, Dejours P: Ventilation and blood acid-base balance of the crayfish as functions of water oxygenation (40-1500 torr). Comp Biochem Physiol A Physiol 1980, 65(4):427-432.

62. Spicer JI, Raffo A, Widdicombe S: Influence of $\mathrm{CO}_{2}$-related seawater acidification on extracellular acid-base balance in the velvet swimming crab Necora puber. Mar Biol 2007 I5 I(3): I | I7-II 25.

63. Taylor AC, Davies PS: Aquatic respiration in the land crab, Gecarcinus lateralis (Fréminville). Comp Biochem Physiol A Physiol 1982, 72(4):683-688.

64. Taylor EW, Wheatly MG: The effect of long-term aerial exposure on heart rate, ventilation, respiratory gas exchange and acid-base status in the crayfish Austropotamobius pallipes. J Exp Biol I98I, 92(Jun): 109-124

65. Taylor EW, Whiteley NM: Oxygen transport and acid-base balance in the haemolymph of the lobster, Homarus gammarus, during aerial exposure and resubmersion. J Exp Biol 1989, | 44:417-436.

66. Truchot JP: Blood acid-base changes during experimental emersion and reimmersion of the intertidal crab Carcinus maenas (L.). Respir Physiol 1975, 23(3):35I-360.

67. Varley DG, Greenaway P: The effect of emersion on hemolymph acid-base balance and oxygen levels in Scylla serrata Forskal (Brachyura: Portunidae). J Exp Mar Biol Ecol 1992, 163(1):1-12.

68. Weber RE, Hagerman L: Oxygen and carbon dioxide transport ing qualities of hemocyanin in the hemolymph of a natant decapod Palaemon adspersus. Journal of Comparative Physiology I98I, I 45(I):2I-27.

69. Wheatly MG, Mcmahon BR: Responses to hypersaline exposure in the euryhaline crayfish Pacifastacus leniusculus. I. The interaction between ionic and acid-base regulation. J Exp Biol 1982, 99(Aug):425-445.

70. Wilkes PRH, McMahon BR: Effect of maintained hypoxic exposure on the crayfish Orconectes rusticus. I. Ventilatory, acid- base and cardiovascular adjustments. I Exp Biol 1982 , 98(Jun): I 19-137.

7I. Pirow R, Buchen I: The dichotomous oxyregulatory behaviour of the planktonic crustacean Daphnia magna. J Exp Biol 2004 207(4):683-696.

72. Schmidt-Nielsen K: Scaling: Why is animal size so important? Cambridge: Cambridge University Press; 1984.

73. Pirow R, Bäumer C, Paul RJ: Benefits of haemoglobin in the cladoceran crustacean Daphnia magna. J Exp Biol 200I, 204(20):3425-344I.

74. Seidl MD, Paul RJ, Pirow R: Effects of hypoxia acclimation on morpho-physiological traits over three generations of Daphnia magna. J Exp Biol 2005, 208(I I):2 I65-2I 75 .

75. Seidl MD, Pirow R, Paul RJ: Acclimation of the microcrustacean Daphnia magna to warm temperatures is dependent on haemoglobin expression. J Therm Biol 2005, 30(7):532-544.

76. Pirow R, Baumer C, Paul RJ: Crater landscape: two-dimensional oxygen gradients in the circulatory system of the microcrustacean Daphnia magna. J Exp Biol 2004, 207(25):4393-4405.

77. Morgan DO, McMahon BR: Acid tolerance and effects of sublethal acid exposure on iono-regulation and acid-base status in two crayfish Procambarus clarki and Orconectes rusticus. J Exp Biol I 982, 97(Apr):24I-252

78. Wood CM, Rogano MS: Physiological responses to acid stress in crayfish (Orconectes): Hemolymph ions, acid-base status, and exchanges with the environment. Can J Fish Aquat Sci I986, 43(5): $1017-1026$

79. Jensen $\mathrm{FB}$, Malte $\mathrm{H}$ : Acid-base and electrolyte regulation, and hemolymph gas transport in crayfish, Astacus astacus, exposed to soft, acid water with and without aluminum. J Comp Physiol B 1990, 160(5):483-490.

80. McMahon BR, Morgan DO: Acid toxicity and physiological responses to sub-lethal acid exposure in crayfish. In Freshwater crayfish V: Papers from the fifth international symposium on freshwater crayfish Edited by: Goldman CR. Westport: AVI Publishing; 1983:7|-85.

81. Malley DF: Decreased survival and calcium uptake by the crayfish Orconectes virilis in low pH. Can J Fish Aquat Sci 1980, 37(3):364-372.

82. France RL: Response of the crayfish Orconectes virilis to experimental acidification of a lake with special reference to the importance of calcium. In Freshwater crayfish V: Papers from the fifth international symposium on freshwater crayfish Edited by: Goldman CR. Westport: AVI Publishing; 1983:98-III.

83. Zanotto FP, Wheatly MG: The effect of ambient pH on electrolyte regulation during the postmolt period in freshwater crayfish Procambarus clarkii. J Exp Biol 1993, 178:1-19.

84. Kring RL, O'Brien WJ: Effect of varying oxygen concentrations on the filtering rate of Daphnia pulex. Ecology 1976, 57(4):808-8I4.

85. Glazier DS: Separating the respiration rates of embryos and brooding females of Daphnia magna: Implications for the cost of brooding and the allometry of metabolic rate. Limnol Oceanogr 1991, 36(2):354-362.

86. Sterba G: Zytologische Untersuchungen an grosskernigen Fettzellen von Daphnia pulex unter besonderer Berücksichtigung des Mitochondrien-Formwechsels. Z Zellforsch Mikrosk Anat 1956, 44(5):456-487.

87. Tessier AJ, Goulden CE: Estimating food limitation in cladoceran populations. Limnol Oceanogr 1982, 27(4):707-717.

88. Bodar CWM, van Donselaar EG, Herwig HJ: Cytopathological investigations of digestive tract and storage cells in Daphnia magna exposed to cadmium and tributyltin. Aquat Toxicol 1990, 17(4):325-338.

89. Green J: Carotenoids in Daphnia. Proc R Soc Lond Ser B Biol Sci 1957, I 47(928):392-40 I

90. Goldmann T, Becher B, Wiedorn KH Pirow R, Deutschbein ME, Vollmer E, Paul RJ: Epipodite and fat cells as sites of hemoglobin synthesis in the branchiopod crustacean Daphnia magna. Histochem Cell Biol 1999, I I 2(5):335-339.

91. Zaffagnini F, Zeni C: Considerations on some cytological and ultrastructural observations on fat cells of Daphnia (Crustacea, Cladocera). Boll Zool I986, 53(I):33-39.

92. Olmstead AW, Leblanc GA: Juvenoid hormone methyl farnesoate is a sex determinant in the crustacean Daphnio magna. J Exp Zool 2002, 293(7):736-739. 
93. Rider CV, Gorr TA, Olmstead AW, Wasilak BA, Leblanc GA: Stress signaling: coregulation of hemoglobin and male sex determination through a terpenoid signaling pathway in a crustacean. J Exp Biol 2005, 208(I): I5-23.

94. Seymour R, Cowgill UM, Klecka GM, Gersich FM, Mayes MA: Occurrence of Aphanomyces daphniae infection in laboratory cultures of Daphnia magna. J Invertebr Pathol I984, 43( I): I09-I I3.

95. Stazi AV, Mantovani A, Fuglieni F, Didelupis GLD: Observations on fungal infection of the ovary of laboratory-cultured Daphnia magna. Bull Environ Contam Toxicol 1994, 53(5):699-703.

96. France RL, Graham L: Increased microsporidian parasitism of the crayfish Orconectes virilis in an experimentally acidified lake. Water Air Soil Pollut 1985, 26(2): I29-136.

97. Ebert D: Ecology, epidemiology, and evolution of parasitism in Daphnia [Internet]. Bethesda (MD): National Library of Medicine (US), National Center for Biotechnology Information; 2005.

98. Havas M, Likens GE: Changes in ${ }^{22} \mathrm{Na}$ influx and outflux in Daphnia magna (Straus) as a function of elevated Al concentrations in soft water at low pH. Proc Natl Acad Sci USA 1985, 82(2I):7345-7349.

99. Havas M, Hutchinson TC: Effect of low pH on the chemical composition of aquatic invertebrates from tundra ponds at the Smoking Hills, N.W.T. Canada. Can J Zool I 983, 6 I (I):24I-249.

100. Stobbart RH, Keating J, Earl R: A study of sodium uptake by the water flea Daphnia magna. Comp Biochem Physiol A Physiol 1977, 58(3):299-309.

I0I. Bianchini A, Wood CM: Physiological effects of chronic silver exposure in Daphnia magna. Comp Biochem Physiol C Toxicol Pharmacol 2002, I33(I-2): 137-145.

102. Kobayashi M: Estimation of the haemolymph volume in Daphnia magna by haemoglobin determination. Comp Biochem Physiol A Physiol 1983, 76(4):803-805.

103. Holm-Jensen I: Osmotic regulation in Daphnia magna under physiological conditions and in the presence of heavy metals. K Dan Vidensk Selsk Biol Medd 1948, 20: I-64.

104. Roughton FJW: Some recent work on the chemistry of carbon dioxide transport by blood. The Harvey lectures 1943, 29:96-|42.

105. Gray BA: The rate of approach to equilibrium in uncatalyzed $\mathrm{CO}_{2}$ hydration reactions: The theoretical effect of buffering capacity. Respir Physiol I 97I, I I (2):223-234.

106. Aldridge JB, Cameron JN: $\mathbf{C O}_{2}$ exchange in the blue crab, Callinectes sapidus (Rathbun). J Exp Zool 1979, 207(2):321-328.

107. Burnett LE, Woodson PBJ, Rietow MG, Vilicich VC: Crab gill intraepithelial carbonic anhydrase plays a major role in haemolymph $\mathrm{CO}_{2}$ and chloride ion regulation. J Exp Biol 198I, 92(Jun):243-254.

108. Henry RP, Cameron JN: The distribution and partial characterization of carbonic anhydrase in selected aquatic and terrestrial decapod crustaceans. J Exp Zool 1982, 22 I(3):309-32I.

109. Cameron JN, Heisler N: Acid-base equilibria in invertebrates. In Acid-Base Regulation in Animals Amsterdam: Elsevier; 1986:357-394.

I 10. Keen RE, Spain JD: Computer simulation in biology: a BASIC introduction. New York: Wiley-Liss; 1991.

III. Swietach P, Leem CH, Spitzer KW, Vaughan-Jones RD: Experimental generation and computational modeling of intracellular pH gradients in cardiac myocytes. Biophys J 2005, 88(4):3018-3037.

I 12. Pirow R: The contribution of hemoglobin to oxygen transport in the microcrustacean Daphnia magna - A conceptual approach. Adv Exp Med Biol 2003, 51 0:101-107.

I13. Krogh A: The rate of diffusion of gases through animal tissue, with some remarks on the coefficient of invasion. J Physiol (Lond) 1919, 52:391-408.

I14. Dejours P: Principles of comparative respiratory physiology. Amsterdam: Elsevier/North-Holland Biomedical Press; 1981.

I 15. Martin JW: Concise encyclopedia of the structure of animals. Amsterdam: Elsevier; 2006.

II6. wFleaBase: FlyBase: Daphnia water flea genome database. [http://wFleaBase.org]

I I7. JGI: Joint Genome Institute. [http://www.jgi.doe.gov/Daphnia].

I 18. Hewett-Emmett D, Tashian RE: Functional diversity, conservation, and convergence in the evolution of the $\alpha-, \beta-$, and $\gamma$-carbonic anhydrase gene families. Mol Phylogenet Evol 1996, 5(I):50-77.

I 19. FlyBase: A database of Drosophila genes \& genomes. [http:// flybase.org].
120. Gouet P, Robert X, Courcelle E: ESPript/ENDscript: Extracting and rendering sequence and $3 D$ information from atomic structures of proteins. Nucleic Acids Res 2003, 3 I ( I 3):3320-3323.

121. Kimber MS, Pai EF: The active site architecture of Pisum sativum $\beta$-carbonic anhydrase is a mirror image of that of $\alpha$-carbonic anhydrases. EMBO J 2000, I9(7):|407-1418.

122. Risler JL, Delorme MO, Delacroix H, Henaut A: Amino acid substitutions in structurally related proteins - a pattern recognition approach: Determination of a new and efficient scoring matrix. Journal of Molecular Biology 1988, 204(4): I019-1029.

123. Castro Nda S, Maia ZA, Pereira M, Soares CM: Screening for glycosylphosphatidylinositol-anchored proteins in the Paracoccidioides brasiliensis transcriptome. Genet Mol Res 2005 4(2):326-345.

124. Serrano L, Halanych KM, Henry RP: Salinity-stimulated changes in expression and activity of two carbonic anhydrase isoforms in the blue crab Callinectes sapidus. J Exp Biol 2007 2 I 0(I3):2320-2332.

125. Smith KE, VanEkeris LA, Linser PJ: Cloning and characterization of AgCA9, a novel $\alpha$-carbonic anhydrase from Anopheles gambiae Giles sensu stricto (Diptera: Culicidae) larvae. J Exp Biol 2007, 21 0(22):3919-3930.

126. Geers C, Gros G: Carbon dioxide transport and carbonic anhydrase in blood and muscle. Physiol Rev 2000, 80(2):68I-7I5.

127. Gilmour KM: The disequilibrium pH: A tool for the localization of carbonic anhydrase. Comp Biochem Physiol A Mol Integr Physiol 1998, I I 9(I):243-254

128. Elendt BP, Bias WR: Trace nutrient deficiency in Daphnia magna cultured in standard medium for toxicity testing. Effects of the optimization of culture conditions on life history parameters of D. magna. Water Res 1990, 24(9): | | 57- I I67.

129. Walton WE, Compton SM, Allan JD, Daniels RE: The effect of acid stress on survivorship and eeproduction of Daphnia pulex (Crustacea, Cladocera). Can J Zool 1982, 60(4):573-579.

130. Paul RJ, Colmorgen M, Hüller S, Tyroller F, Zinkler D: Circulation and respiratory control in millimetre-sized animals (Daphnia magna, Folsomia candida) studied by optical methods. J Comp Physiol B Biochem Syst Environ Physiol 1997, I67(6):399-408.

I3I. Truchot JP: Comparative aspects of extracellular acid-base balance. Berlin: Springer-Verlag; 1987.

132. Stewart PA: Independent and dependent variables of acidbase control. Respir Physiol 1978, 33(I):9-26.

133. Duan Z, Sun R: An improved model calculating $\mathbf{C O}_{2}$ solubility in pure water and aqueous $\mathrm{NaCl}$ solutions from 273 to $533 \mathrm{~K}$ and from 0 to 2000 bar. Chem Geol 2003, I 93(3-4):257-27I.

134. Duan Z, Sun R, Zhu C, Chou I-M: An improved model for the calculation of $\mathrm{CO}_{2}$ solubility in aqueous solutions containing $\mathrm{Na}^{+}, \mathrm{K}^{+}, \mathrm{Ca}^{2+}, \mathrm{Mg}^{2+}, \mathrm{Cl}^{-}$, and $\mathrm{SO}_{4}{ }^{2-}$. Mar Chem 2006, 98(24): $|3|-139$

135. Burton RF: The roles of buffers in body fluids: mathematical analysis. Respir Physiol 1973, I 8(I):34-42.

136. Heisler $N$ : Buffering and transmembrane ion transfer processes. In Acid-base regulation in animals Edited by: Heisler N. Amsterdam: Elsevier; 1986:3-47.

137. Frans SD, Harris JM: Reiterative least-squares spectral resolution of organic/acid base mixtures. Anal Chem 1984 56(3):466-470.

138. Green J: Growth, size and reproduction in Daphnia (Crustacea: Cladocera). Proc Zool Soc Lond 1956, I 26: I 73-204.

139. Vandegriff KD, Shrager RI: Hemoglobin-oxygen equilibrium binding: Rapid-scanning spectrophotometry and singular value decomposition. In Methods in Enzymology, Hemoglobins, Part C: Biophysical methods Volume 232. Edited by: Everse J, Vandengriff KD, Winslow RM. New York: Academic Press; 1994:460-485.

140. Stumm W, Morgan Jj: Aquatic Chemistry. New York: John Wiley \& Sons, Inc; 1995.

14I. Portielje R, Lijklema L: Carbon dioxide fluxes across the airwater interface and its impact on carbon availability in aquatic systems. Limnol Oceanogr 1995, 40(4):690-699.

142. Tellinghuisen J: A simple, all-purpose nonlinear algorithm for univariate calibration. Analyst 2000, I 25(6): I 045-1048.

143. Tellinghuisen J: Simple algorithms for nonlinear calibration by the classical and standard additions methods. Analyst 2005, I 30(3):370-378. 
144. Press WH, Teukolsky SA, Vetterling WT, Flannery BP: Numerical recipes in C: The art of scientific computing. 2nd edition. Cambridge: Cambridge University Press; 1992.

145. CDD: Conserved Domain Database. [http:// www.ncbi.nlm.nih.gov/Structure/cdd/cdd.shtml].

146. Marchler-Bauer A, Anderson JB, Derbyshire MK, DeWeese-Scott C, Gonzales NR, Gwadz M, Hao LN, He SQ, Hurwitz DI, Jackson JD, et al.: CDD: a conserved domain database for interactive domain family analysis. Nucleic Acids Res 2007, 35:D237-D240.

147. NCBI blastp [http://www.ncbi.nlm.nih.gov/blast/Blast.cgi]

148. SignalP 3.0 server [http://www.cbs.dtu.dk/services/SignalP/]

149. Bendtsen JD, Nielsen H, von Heijne G, Brunak S: Improved prediction of signal peptides: SignalP 3.0. J Mol Biol 2004, 340(4):783-795.

150. Emanuelsson O, Brunak S, von Heijne G, Nielsen H: Locating proteins in the cell using TargetP, SignalP and related tools. Nature Protocols 2007, 2(4):953-97I.

I5I. GPI-SOM: Identification of GPI-anchor signals. [http:// gpi.unibe.ch].

152. Fankhauser N, Maser P: Identification of GPI anchor attachment signals by a Kohonen self-organizing map. Bioinformatics 2005, 2 I(9): | 846- | 852.

I53. big-PI Predictor: GPI modification site prediction. [http://men del.imp.ac.at/sat/gpi/gpi server.html].

I54. Eisenhaber B, Bork P, Eisenhaber F: Prediction of potential GPImodification sites in proprotein sequences. J $\mathrm{Mol} \mathrm{Biol} 1999$, 292(3):74|-758.

155. FragAnchor: GPI-anchored protein prediction [http:// navet.ics.hawaii.edu/ fraganchor/NNHMM/NNHMM.html]

156. Poisson G, Chauve C, Chen X, Bergeron A: FragAnchor: A largescale predictor of glycosylphosphatidylinositol anchors in eukaryote protein sequences by qualitative scoring. Geno Prot Bioinfo 2007, 5(2): | 21 - | 30.

I57. T-Coffee: multiple sequence alignment tool [http://www.tcof fee.org]

158. Notredame C, Higgins DG, Heringa J: T-Coffee: A novel method for fast and accurate multiple sequence alignment. J Mol Biol 2000, 302(I):205-217.

159. Poirot O, O'Toole E, Notredame C: Tcoffee@igs: a web server for computing, evaluating and combining multiple sequence alignments. Nucleic Acids Res 2003, 3 I (13):3503-3506.

160. ESPript: PostScript output from aligned sequences [http:// espript.ibcp.fr/ESPript/cgi-bin/ESPript.cgi]

161. Gouet P, Courcelle E, Stuart DI, Metoz F: Analysis of multiple sequence alignments in PostScript. Bioinformatics 1999 , I 5(4):305-308.

162. Saitou N, Nei M: The neighbor-joining method: A new method for reconstructing phylogenetic trees. Mol Biol Evol 1987, 4(4):406-425

163. iTOL: Interactive Tree Of Life. [http://itol.embl.de].

164. Letunic I, Bork P: Interactive Tree Of Life (iTOL): an online tool for phylogenetic tree display and annotation. Bioinformatics 2007, 23(I): 127-I28.
Publish with Bio Med Central and every scientist can read your work free of charge

"BioMed Central will be the most significant development for disseminating the results of biomedical research in our lifetime. "

Sir Paul Nurse, Cancer Research UK

Your research papers will be:

- available free of charge to the entire biomedical community

- peer reviewed and published immediately upon acceptance

- cited in PubMed and archived on PubMed Central

- yours - you keep the copyright
BioMedcentral 